\title{
When "Best Practices" Win, Employees Lose: Symbolic Compliance and Judicial Inference in Federal Equal Employment Opportunity Cases
}

\author{
Linda Hamilton Krieger, Rachel Kahn Best, and Lauren B. Edelman
}

\begin{abstract}
This article provides a new account of employers' advantages over employees in federal employment discrimination cases. We analyze the effects of judicial deference, in which judges use institutionalized employment structures to infer nondiscrimination without scrutinizing those structures in any meaningful way. Using logistic regression to analyze a representative sample of judicial opinions in federal EEO cases during the first thirty-five years after the passage of the 1964 Civil Rights Act, we find that when judges uncritically use the presence of organizational structures to reason about whether discrimination occurred, employers are much more likely to prevail. This pattern is especially pronounced in opinions written by liberal judges. In light of these findings, we offer recommendations for judges, lawyers, and policy makers-including legal academics-who seek to improve the accuracy and efficacy of employment discrimination adjudications.
\end{abstract}

Linda Hamilton Krieger (lkrieger@hawaii.edu) is a Professor of Law and Director of the Ulu Lehua Scholars Program at the University of Hawai'i William S. Richardson School of Law.

Direct correspondence regarding this article to Professor Linda Hamilton Krieger, University of Hawaii, William S. Richardson School of Law, 2515 Dole St., Honolulu, Hl; lkrieger@hawaii.edu; 1 808-838-9597.

Rachel Kahn Best (rkb@umich.edu) is an Assistant Professor of Sociology at the University of Michigan.

Lauren B. Edelman (ledelman@law.berkeley.edu) is the Agnes Roddy Robb Professor of Law and Professor of Sociology at the University of California, Berkeley.

This article is the third in a series of three deriving from the same data set. The earlier articles are: Edelman, Krieger, Eliason, Albiston, and Mellema, 2011, When Organizations Rule: Judicial Deference to Institutionalized Employment Structures, American Journal of Sociology 117 (3): 888-954 and Best, Edelman, Krieger, and Eliason, 2011, Multiple Disadvantages: An Empirical Test of Intersectionality Theory in EEO Litigation, Law \& Society Review 45 (4): 991-1025. Data collection, coding, and analysis for this article, along with the two articles cited above, were supported by a grant from the National Science Foundation (SES 0651870) and by grants from the California (UC) Committee on Research and the UC Berkeley School of Law. Some of the work of data collection, coding, and analy. sis was conducted while Linda Krieger was a fellow at the Radcliffe Institute for Advanced Study at Harvard University, while Lauren Edelman was a fellow at the Center for Advanced Study in the Behavioral Sciences in Stanford, California, and while Rachel Best was a Robert Wood Johnson Foundation Scholar in Health Policy Research at the University of Michigan. We thank the Discrimination Research Group, funded by the American Bar Foundation, the Center for Advanced Study in the Behavioral Sciences, and the Ford Foundation for an invigorating exchange that influenced many of the ideas in this article. We also thank Aaron Smyth for outstanding research assistance. Authorship was fully collaborative. 


\section{INTRODUCTION}

That the "haves" come out ahead in civil disputing (Galanter 1974) is now a commonplace argument with substantial empirical support. The sociolegal literature inspired by Galanter's work specifies numerous mechanisms that, over time, systematically advantage better-resourced and better-organized repeat players at the expense of less well-resourced one-shotters (Stigler 1971; Blumrosen 1993; Songer and Sheehan 1993; Albiston 1999; Edelman and Suchman 1999; Thornburg 1999; Leech et al. 2002, Kamieniecki 2006; Krieger 2007; Quintanilla 2011; Gertner 2012).

In this article, we highlight a new source of inequality in civil litigation by bringing together hypotheses drawn from two literatures that have until now proceeded largely independently: the neoinstitutional literature on law and organizations and research on judicial ideology. In addition, we draw on studies of judicial cognition to help explain our findings and, more generally, to explain the connection between institutionalized structures in organizations, judicial ideology, and outcomes in civil rights cases. Using a representative sample of federal civil rights cases decided during the first thirty-five years after the passage of the 1964 Civil Rights Act, we explore the interplay between judicial ideology, judicial deference to organizational structures, and case outcome. We find that when judges use the presence of organizational structures (i.e., policies, practices, offices, and officers) to reason about whether discrimination occurred without scrutinizing the adequacy of those structures, employers are much more likely to prevail. The fact that judges use institutionalized employment structures heuristically to infer nondiscrimination helps explain employers' increasing advantage in EEO litigation.

We also show that judicial ideology and judicial deference interact in a surprising way: the effect of judges' uncritical deference to organizational structures is especially pronounced in opinions written by liberal judges, even though, all else equal, liberal judges tend to be more pro-plaintiff. Plaintiff win rates decline more when liberal judges defer to institutionalized organizational structures than when conservative judges defer to these structures. These findings have important implications for both judges and lawyers, and they suggest the need to consider institutionalized organizational structures in explaining judicial decision making with respect to laws regulating organizations.

\section{INFLUENCES ON JUDICIAL REASONING}

In this section, we very briefly review three literatures that inform our project and findings. The judicial ideology literature, found primarily in political science, suggests the importance of judges' political orientations in predicting case outcomes. The neoinstitutional literature on law and organizations, found primarily in sociology, informs our attention to institutionalized organizational structures. Our analysis focuses on variables derived from these two literatures. However, we also briefly review the judicial cognition literature, found primarily in law and behavioral 
economics, because this research provides a possible explanation for how institutionalized organizational structures affect judicial decision making.

\section{Judicial Ideology}

Sociolegal scholars have long been skeptical of the legal formalist idea that judges are impartial or unswayed by political, economic, and social interests. A voluminous literature in political science reveals that politics, attitudes, strategic considerations, and historical and cultural influences affect judicial reasoning and judicial decisions. Focusing primarily, but not exclusively, on the Supreme Court, political scientists have asked why judges decide cases as they do and what influences their decisions beyond the reasons given in their written opinions.

The attitudinal approach emphasizes judges' ideological values as an important influence beyond the facts of the case (Pritchett 1948; Segal and Cover 1989; Baum 1992; Segal and Spaeth 1993, 1996, 2002; Spaeth and Segal 1999). For example, in a comprehensive analysis of the federal judiciary covering twenty-four areas of law, Sunstein et al. (2006) find that federal judges appointed by Democratic presidents vote in ways that can be characterized as liberal 52 percent of the time overall, whereas federal judges appointed by Republican presidents vote liberal 40 percent of the time. They argue that partisan voting emerges in the context of legal ambiguity: in cases where there is no clear legal answer, attitudes and political ideology come into play. Importantly, the impact of judicial ideology is strongest at the Supreme Court level, somewhat less strong at the appellate level, and weakest at the district court level, possibly because lower court judges are more concerned with avoiding reversals by higher court judges (Pinello 1999). The composition of judicial panels matters as well: individual judges' politics are moderated on a mixed panel and exacerbated on a panel of judges with similar ideological views (Revesz 1997; Sunstein, Schkade, and Ellman 2004; Sunstein et al. 2006). Judges, according to the attitudinal approach, are essentially politicians in robes (Epstein and Knight 2013).

Strategic choice scholars qualify the attitudinal model by suggesting that, especially on the Supreme Court, judges and justices do not act only according to their ideological preferences, but also take into account the preferences and actions of other relevant actors, such as their colleagues, elected officials, and the public (Eskridge 1991a, 1991b; Knight and Epstein 1996; Cross and Tiller 1998; Epstein and Knight 1998, 2000; Wahlbeck, Spriggs, and Maltzmann 1998; Epstein and Martin 2010). Historical institutionalists argue that contexts, traditions, norms, and cognitive structures help constitute judges' preferences and behaviors (Clayton and Gillman 1999; Maveety 2003; McGuire 2004). Feeley and Rubin (1999) take even a stronger stand, suggesting that at least in the arena of prison reform, judges engage in purposive policy making. As economists, law professors, and psychologists join political scientists in the study of judicial behavior, the list of motivations that scholars find to influence judicial behavior is ever-growing (Posner 1993; Guthrie, Rachlinski, and Wistrich 2007; Rachlinski et al. 2009; Ramji-Nogales, Schoenholtz, and Schrag 2009; Shepherd 2009; Epstein and Knight 2013). 
Although these modifications to the attitudinal approach are important, virtually all scholars of judicial behavior agree that judicial ideology is an important predictor of case outcome, especially in higher courts. Gibson $(1983,9)$ aptly summarized the political science literature on judicial behavior when he wrote that "judges' decisions are a function of what they prefer to do, tempered by what they think they ought to do, but constrained by what they perceive it feasible to do."

\section{Judicial Deference to Institutionalized Organizational Structures}

Judicial deference to institutionalized organizational structures has not received much attention in the political science literature. However, a robust neoinstitutional literature on law and organizations suggests that organizations respond to ambiguous law, and to the legal environment generally, by creating a variety of symbolic legal structures designed to signal attention to law and thus confer legitimacy (Edelman 1990, 1992; Sutton et al. 1994; cf. Kelly 2003). In the context of civil rights law, which tends to be highly ambiguous, organizations create specific compliance structures like EEO offices and discrimination grievance procedures. They also formalize their personnel practices by creating structures like progressive discipline policies and formal multiperson decision-making bodies. Over the first few decades after the enactment of the civil rights legislation of the 1960s, these structures became widely accepted, or institutionalized, as evidenced by their diffusion across organizations (Edelman 1990, 1992; Dobbin et al. 1993; Sutton and Dobbin 1996; Edelman and Petterson 1999; Edelman, Uggen, and Erlanger 1999; Marshall 2005; Dobbin 2009).

Importantly, empirical work has established that these organizational structures, although they appear to further legal ideals, are often ineffective (Baron, Mittman, and Newman 1991; Edelman and Petterson 1999; Edelman, Fuller, and Mara-Drita 2001; Kalev, Dobbin, and Kelly 2006). Studies of complex organizations consistently show that their informal cultures and concrete actions often vary significantly from their formal policies (Roethlisberger and Dickson 1939; Selznick 1949, 1957; Burawoy 1979; Edwards 1979; Gordon, Edwards, and Reich 1982; Scott and Davis 2007). Thus, organizations adopt antidiscrimination policies, but often decouple their formal policies from their informal practice (Weick 1976; Edelman 1992). They create special EEO compliance offices and affirmative action managers, but give those offices and managers no real authority to change discriminatory organizational behavior (Stone 1975; Edelman 1990; Chambliss 1996; Edelman and Suchman 1999). They institute performance evaluation procedures and progressive discipline policies, but fail to discern when managers use these policies to cover up discrimination rather than to prevent it (Bisom-Rapp 1999). Managerial rhetoric reframes affirmative action and antidiscrimination policies as diversity management, which weakens the original policy aims of antidiscrimination law by broadening the categories along which diversity is sought (e.g., diversity of dress style as well as racial diversity) and by reframing sociopolitical problems (e.g., racism, sexism) as interpersonal ones (e.g., personality conflicts or communication failures) (Edelman, Fuller, and Mara-Drita 2001). Overall, while structures that involve tangible goals 
for which the organization will be held accountable (such as OFCCP compliance agreements containing goals and timetables for the hiring or promotion of females and minorities) are effective in increasing the ranks of female and minority managers, many of the most common structures, such as diversity evaluations, diversity training, and minority networking programs, do little to improve the status of women and minorities and may even harm minority groups (Kalev, Dobbin, and Kelly 2006).

Legal endogeneity theory (Edelman 2005, 2007) suggests that ideas about compliance that originate in organizational fields eventually influence thinking in the legal sphere as well. As compliance with civil rights law is increasingly associated with the creation of internal legal structures like antidiscrimination policies, lawyers and judges begin to infer compliance and rationality from the mere presence of institutionalized organizational structures. These views are reinforced by employment lawyers, who engage in what might be called preventive lawyering by reassuring clients that compliance structures can protect organizations from EEO liability (Bisom-Rapp 1999). Employer-side lawyers subsequently advance these arguments to judges (Grossman 2003). Even employees who seek to mobilize EEO rights, or the plaintiff-side lawyers they consult, may believe that the presence of formal, institutionalized structures either equates to compliance with EEO laws or will make suspect employment decisions too expensive or difficult to challenge legally (Bisom-Rapp 1999).

Legal endogeneity theory holds that just as employees and employers are influenced by managerialized conceptions of law, judges tend to take their cues from norms and practices that become institutionalized in organizations (Edelman 2005, 2007; Edelman et al. 2011). Most federal judges have served in leadership roles within public or private organizations and have represented large organizational clients (Purcell 1992; Yoon 2003; Schneider 2005). By the time they take the bench, judges' legal consciousness has likely been significantly influenced by managerial and business logics. Thus, even though none of the EEO statutes explicitly requires that organizations adopt any particular organizational structures to comply with the law, judges began to think of structures as proof of compliance and good faith, even in the absence of evidence of the structures' effectiveness at preventing discrimination.

Edelman et al. (2011) provide empirical support for legal endogeneity theory and specifically for the idea that judges defer to the mere presence of institutionalized organizational structures when they reason about the presence or absence of discrimination. Using a representative sample of federal employment discrimination opinions issued during the first thirty-five years after passage of the 1964 Civil Rights Act, the authors examined patterns over time of three indicia of legal endogeneity: first, whether judges mentioned organizational structures in their opinions; second, whether judges indicated that the presence of organizational structures was relevant to whether discrimination had occurred; and third, whether judges deferred to organizational structures, that is, used structures to infer nondiscrimination without explicitly scrutinizing those structures' effectiveness or adequacy.

Edelman et al. (2011) found increasing relevance of and deference to organizational structures over time, as those structures became increasingly institutionalized. 
They found that judges were especially likely to look for signs of organizational rationality where the applicable legal doctrine requires them to evaluate aspects of employer behaviors that are not directly observable-for example, in disparate treatment cases, which require judges to infer employer intent from circumstantial evidence (Edelman et al. 2011). The inherent difficulty of ascertaining intent, coupled with the legal presumption that discrimination is aberrant (Krieger 1995, 1998; Krieger and Fiske 2006) may lead courts to look for signs or symptoms of apparent employer legitimacy or rationality. In fact, Edelman et al. (2011) found that judges were even more likely to defer to structures in disparate treatment cases than in hostile work environment cases, in which organizational structures, such as grievance procedures and antiharassment policies, were made relevant by Supreme Court decisions like Faragher v. City of Boca Raton (1998) and Burlington Industries v. Ellerth (1998).

Edelman et al.'s (2011) findings suggest that organizational structures play an important role in judicial decision making. However, they did not explore the relationship between judicial deference and case outcome or the interactions between judicial deference and judicial politics.

\section{Cognitive Constraints on Judicial Decision Making}

Recent empirical work in cognitive social psychology supplies a third lens through which judicial decision making in employment discrimination litigation can be examined. Specifically, studies of judicial cognition provide insights into how the presence of symbolic institutionalized structures might influence judges' decision making - either alone at the district court level, or with other judges in circuit court decisions produced by three-judge or en banc panels.

Research on judicial cognition suggests that judges-like everyone else-apply two different systems of reasoning: one that is intuitive, heuristic based, and fast and a second that is deliberative, rule based, and slow (Kahneman and Frederick 2002; Frederick 2005; Guthrie, Rachlinski, and Wistrich 2007; Rachlinski 2011). The first of these, sometimes referred to as System 1 (Kahneman and Frederick 2002), allows judges to make rapid decisions in complex cases, but it is significantly susceptible to judgment error. These errors can be corrected through more deliberative System 2 processes (Kahneman and Frederick 2002; Guthrie, Rachlinski, and Wistrich 2007; Rachlinski 2011). However, System 2 processing requires time, effort, and motivation. It is less likely to occur in time-pressured situations or in situations where nothing in the decision-making environment induces deliberation (Guthrie, Rachlinski, and Wistrich 2007; Brest and Krieger 2010).

Judges, like laypeople, operate under conditions of cognitive constraint. Consequently, they sometimes form intuitive judgments about the cases they must decide through the application of fast, intuitive System 1 processes. This subjects their judgment to the effects of numerous biases and heuristics (Guthrie, Rachlinski, and Wistrich 2001, 2002, 2007; Wistrich, Guthrie, and Rachlinski 2005; Rachlinski 2011; Fraidin 2013; Rachlinski, Wistrich, and Guthrie 2013; Powers 2014).

For example, judges, like other people, are subject to anchoring and framing effects (Guthrie, Rachlinski, and Wistrich 2001; Wistrich, Guthrie, and Rachlinski 
2005) and to hindsight bias (Kamin and Rachlinski 1995; Rachlinski 1998; Gulati, Rachlinski, and Langevoort 2004). In judging the likelihood that a particular event occurred, judges, like laypeople, tend to overrely on intuitive hunches at the expense of statistical information, neglecting base rate probabilities and relying instead on a mental shortcut known as the representativeness heuristic (Guthrie, Rachlinski, and Wistrich 2001).

Recent research on judicial cognition has also shown that judges are subject to the effects of primes, legally nonrelevant facts to which they are exposed during the decision-making process, which focus their attention in a particular direction (Rachlinski, Wistrich, and Guthrie 2013). Left unadjusted by deliberative System 2 processing, primes can unwittingly alter judges' reasoning in ways not responsive to applicable legal rules and principles.

These cognitive constraints on judicial inference help to explain at a micro level the impact of institutionalized employment practices that neoinstitutional scholars observe at a macro level. Specifically, judicial deference to institutionalized employment practices may reflect, at least in part, the operation of uncorrected System 1 processes, through which the presence of institutionalized employment practices primes ideas about employer rationality and fairness, which, in turn, influence judicial inferences about the likelihood that a challenged decision resulted from discriminatory motivation.

\section{JUDICIAL DEFERENCE AND CASE OUTCOME}

In the current study, we extend previous work on judicial decision making and legal endogeneity theory by examining the effect of judicial deference to institutionalized organizational structures on case outcome. Given the importance of judicial ideology in the political science literature, we are particularly interested in the effect of judicial deference, net of the effect of judicial ideology, and in any interaction between judicial deference and judicial ideology.

In examining the effect of judicial deference on case outcome, we expand on previous research. Edelman et al. (2011) treated deference as the dependent variable and sought to explain when and why judges defer to organizational structures. In contrast to Edelman et al. (2011), we treat judicial deference as the key independent variable and seek to explain the impact of judicial deference on case outcome. ${ }^{1}$ Importantly, employers may either win or lose a case in which deference to a structure has occurred, both because multiple structures could be considered in a case (some deferred to and others not deferred to) and because factors other than deference can affect case outcome as well. Thus, this study tests the final step in legal endogeneity theory-the effect of judicial deference on case outcome. Further, by examining the independent effects of and interaction between judicial deference and judicial ideology, this study links legal endogeneity theory to extant work on

1. Since a case may discuss multiple organizational structures, Edelman et al. (2011) used structures as the unit of analysis. Since parties win cases, not structures, our unit of analysis is the case and we measure the effect of the number of structures that the judge deferred to on the employee's chance of winning at least a partial victory. 
judicial decision making. We now turn to the empirical question of whether and, if so, how judicial deference affects case outcome.

\section{DATA AND METHODS}

\section{Sample}

We analyze a random sample of 1,024 federal civil rights opinions written by the federal district and circuit courts from 1965 through 1999. US Supreme Court cases were excluded because of their relatively small numbers and because they affected the outcomes of subsequent cases. The sample includes opinions from cases arising under the following federal civil rights statutes: Title VII of the Civil Rights Act of 1964, the Age Discrimination in Employment Act of 1967, the Equal Pay Act of 1963, and two post-civil war civil rights statutes: 42 USCA Section 1981 and 42 USCA Section 1983. These civil rights statutes all prohibit discrimination against particular classes of employees. ${ }^{2}$

The sample was selected by searching Westlaw for all reported and unreported decisions under these statutes ${ }^{3}$ (34,578 district court opinions and 16,604 circuit court opinions). ${ }^{4}$ Within the district and circuit court samples, we ordered the opinions chronologically and selected every fiftieth case. ${ }^{5}$

All opinions were read and coded by second-and third-year law students who had taken a course in EEO law and received at least 100 hours of coding training. Extensive efforts were undertaken to ensure intercoder reliability, described in detail in Edelman et al. (2011). A large portion of the coding revolved around the treatment of forty-five types of organizational structures, including formal rules, policies, functionaries, and practices. These structures, and the ways in which they can be deferred to, divide into three categories. The first category comprises compliance structures, such as antidiscrimination policies, which explicitly signal attention to

2. The sample excludes cases brought under the Americans with Disabilities Act of 1990 and the Rehabilitation Act of 1973 because the accommodation requirement contained in those statutes made it difficult to assess deference in a standardized manner across opinions. Opinions in cases brought under the Family and Medical Leave Act of 1993 were also excluded due to complicated issues involving notice.

3. Most EEO charges filed never result in a judicial opinion, primarily because many are resolved before reaching this stage (Siegelman and Donohue 1990). Therefore, our data are not representative of all EEO charges. However, since our study focuses on judicial reasoning, the key question is whether our sample is representative of judicial opinions. Since the Westlaw database attempts to include every federal decision, including those that are not legally published, we believe our data are representative of federal judicial opinions.

4. Observing endogeneity through published opinions necessarily misses the impact of endogeneity on cases that do not reach litigation. For example, plaintiffs' lawyers may discourage employees who have not used internal grievance procedures from filing suit for sexual harassment, believing that the employee's failure to use the procedure weakens her case. To the extent that a sample based on Westlaw is unrepresentative, we believe that it will produce conservative estimates of the impact of deference on employees' rights generally.

5. The initially selected cases were reviewed to ensure that they represented merits adjudications of EEO claims arising under any of the above-mentioned statutes. If a selected case did not satisfy this criterion, it was excluded from the sample, and the next case in chronological order was reviewed in the same manner until a qualifying case was identified. 
law. When judges defer to these policies, they are accepting the symbolism of these structures without scrutiny as to whether they are effective. The second category comprises personnel policies, such as employee handbooks, multiperson decisionmaking processes, and progressive discipline systems, which involve rules about governance. When judges defer to these policies, they fail to scrutinize whether or how the structures are implemented within organizations. The third type is business practices, such as reduction in force (RIF) plans, appearance requirements, or the posting of openings. Deference to formalized business practices, which is far less common, usually occurs where a judge writes that an organization is justified in following its own policies, irrespective of how they are carried out and whether they apply generally to all employees. See Appendix 2 for a full list of structures.

\section{Dependent Variable}

Our dependent variable is who wins at this stage of the case. We classify opinions into two categories: complete employer victories and at least partial plaintiff victories. ${ }^{6}$

\section{Independent Variables}

\section{Judicial Deference}

Our key independent variable is judicial deference. Following Edelman et al. (2011), we define judicial deference to organizational structures as occurring when judges use structures as indicators of nondiscrimination without scrutinizing their adequacy or while ignoring strong evidence that the structures are inadequate. Deference occurs (1) when judges fail to consider the adequacy of organizational structures, (2) when judges offer mere lip service to the adequacy of organizational structures, or (3) when judges use structures to infer nondiscrimination even while explicitly acknowledging their inadequacy. We provide examples of each type of deference below.

In the first form of judicial deference, judges do not consider adequacy at all-that is, they use the presence of the structure as evidence of nondiscrimination without ever asking if the structure was designed or operated to prevent bias from affecting decisions, was consistent and even-handedly applied, or was applied

6. Our coding scheme distinguished between employer victories $(n=590)$, mixed outcomes in which the employer won on the principle $(n=5)$, mixed outcomes in which each party won something on principle $(n=91)$, multiple claims in which each party won at least one claim $(n=55)$, mixed outcomes in which the employee won on principle $(n=48)$, and plaintiff victories $(n=232)$. For ease of interpretation of the results, we present logistic regressions of a two-category dependent variable in the main text, asking whether deference makes it more likely that employers will secure a complete victory, keeping plaintiffs from winning anything at all. Our employer victory category includes complete employee victories and the small number of cases coded as mixed outcomes in which the employer won on principle. Reclassifying these five cases as partial plaintiff victories does not substantively affect the results. We classify all other cases as at least partial plaintiff victories. Generalized ordered logistic regressions of a three-category dependent variable (employer victory, mixed outcome, and employee victory) yielded similar results (see Appendix 1). 
properly in a given case. For example, in Grubb v. W. A. Foote Memorial Hospital, Inc. (1984), the Sixth Circuit failed to consider the adequacy of two structures: a grievance procedure and an RIF. In overturning the district court's finding of race discrimination, the circuit court pointed to the fact that the plaintiff had not used the company's formal grievance procedure to complain about his termination (despite the fact that the personnel director told him that it would be "useless" for him to do so). The court used the mere presence of the grievance procedure as evidence of nondiscrimination without investigating its adequacy. Additionally, the district court had concluded that the RIF had been a pretext for race discrimination. In reversing the district court's decision, the circuit court failed to question whether or not there had been a real RIF, despite the fact that the plaintiff was the only employee terminated.

In the second form of judicial deference, judges pay lip service to adequacy: they state that a structure is adequate but also recite facts that self-evidently show that the structure is inadequate. So, for example, the court may note that similarly situated persons outside of the plaintiff's protected class were treated more favorably or less harshly under the structure or note that a formal policy was applied by mistake, but nonetheless state that the structure was adequate. Or, the judge might allow that the plaintiff had shown evidence of procedural irregularities in the application of the structure, but also state that the structure was adequate. In these types of cases, one might describe the court as merely giving lip service to the adequacy of a structure that, by the court's own description, had evident and serious flaws that rendered it irrational, unfair, and not indicative of legal compliance. ${ }^{7}$

For example, in Lacy v. Ameritech (1988), the employer had used a formal evaluation procedure to select employees for an RIF. The plaintiff raised examples of similarly situated whites being treated more favorably under the supposedly neutral rating system used to select employees for the RIF, but the court summarily dismissed these examples as irrelevant. The court also dismissed as irrelevant the fact that the employer had gone back and changed the system for rating employees and that it had significantly underranked the plaintiff on one of the relevant criteria. In this case, while the court stated that the structure was adequate, the text of the opinion suggested that the court was not actually considering the evidence for and against adequacy.

In the third form of judicial deference, plaintiffs attack the adequacy of a structure and the court acknowledges that the structure is deficient, but nonetheless uses the structure to support a finding of nondiscrimination. The Southern District of New York's decision granting the employer's motion for summary judgment in Leopold $v$. Baccarat (2000) provides a stark example of this practice.

In Leopold, the plaintiff employee claimed hostile work environment harassment by her supervisor. In defense, the employer pointed to its policy against harassment and an accompanying harassment complaint procedure. The plaintiff

7. To classify an opinion as involving lip service, we required two coders independently to determine that there was strong evidence in the opinion establishing that the structure was inadequate. Even so, this category is more subjective than the other two forms of judicial deference. Therefore, we ran all models with and without these cases of lip service coded as deference. Our results are very similar when we exclude lip service from the definition of deference (see Appendix 1). 
explicitly argued that merely having an antiharassment policy and a complaint procedure should not protect an employer from liability where, as in her case, the employer's policy or the procedure was flawed in ways that made it ineffective. First, the plaintiff pointed out, and the court acknowledged, that the employer's policy required her first to report the harassment to her immediate supervisor-in this case, the alleged harasser himself. Second, the plaintiff demonstrated that the policy lacked a guarantee that employees reporting harassment would not face retaliation for doing so.

These two features of the employer's policies and procedures, the plaintiff testified, made her and several of her coworkers too afraid to file a harassment complaint with the company before filing a charge of discrimination with the EEOC. In support of her argument that the employer's complaint procedure was materially defective, she pointed out that by failing to provide a harasser bypassing mechanism and an antiretaliation guarantee, the employer's policy and procedure violated EEOC interpretive guidelines on effective antiharassment policies and harassment complaint procedures. Nonetheless, the court used the mere existence of the employer's policy complaint procedure to find for the defendant. Dismissing the EEOC guidance as nonbinding, and the plaintiff's testimony about her and her coworkers' fears of retaliation as "conclusory allegations," the court ruled for the defendant employer, observing that "the law is very clear that any reasonable policy will do." In other words, the court recognized that the structure was inadequate, but nonetheless used it as evidence of nondiscrimination.

Not all judicial treatment of organizational structures constitutes deference. Where judges do scrutinize the adequacy of organizational structures, usually by reviewing whether the structure is fairly and even-handedly applied, calculated and operated to reduce bias, and free of defects that would undermine its efficacy, deference does not occur.

For example, in Schartz v. Unified School District No. 512 (1997), a teacher claimed that he was forced to retire as a result of age discrimination. In its defense, the school district invoked an organizational structure: a progressive discipline policy. The defense explained that after numerous students complained about the plaintiff's obscene and abusive speech, the plaintiff received oral and written warnings, then a last-chance notice, and then termination. In considering the application of the progressive discipline structure, the court considered the plaintiffs allegations of defects in the way the progressive discipline policy was applied. In its opinion granting summary judgment on the plaintiffs age discrimination claim, the court carefully examined the process and found that it was followed adequately. In this example, the court properly interrogated the adequacy of the structure, rather than assuming that the presence of a policy supported an inference of nondiscrimination. Thus, deference did not occur.

In another example, in McDowell v. Mississippi Power $\mathcal{E}$ Light (1986), the plaintiff alleged that she had been denied a promotion as a result of sex discrimination. She was married to another employee and her employer defended on the basis of its antinepotism policy. Rather than assuming that this structure was evidence of nondiscrimination, the court closely examined the terms and the application of the policy. The court noted that the policy had not been applied in many cases 
involving male applicants whose wives worked for the company, that the policy had never been mentioned to the plaintiff until after she filed her complaint, and that the plaintiff's promotion would not actually have violated the precise terms of the policy. Having concluded that the structure was inadequate to prevent gender bias from influencing decision making, the court rendered judgment for the plaintiff. Again, deference did not occur.

In sum, judicial deference to organizational structures exists only where judges treat the mere existence of an organizational structure as evidence of nondiscrimination, irrespective of the adequacy or quality of that structure. Judicial deference to structures does not exist where judges offer even a minimal analysis of the adequacy of structures and deem them either adequate or inadequate.

Thus, we distinguish between structures that were deferred to and those in which judges scrutinized structures and deemed them either adequate or inadequate. Our coding scheme does not measure the accuracy of judges' assessments of structures' adequacy. For our purposes, the key question is whether judges scrutinize a structure's efficacy at all before using it as evidence of nondiscrimination. This makes our definition of deference fairly narrow, excluding many instances in which judges engage in minimal scrutiny of structures. Therefore, our results should be understood as a lower bound on the frequency and effects of judicial deference.

Since judges may defer to multiple structures within a case, we measure judicial deference as a count of the number of times the judge deferred to a structure. We also control for the number of structures judges scrutinized and found adequate or inadequate. ${ }^{8}$

\section{Judicial Ideology}

We measure judges' political ideology using the Giles, Hettinger, and Peppers (2001) method. ${ }^{9}$ This measure takes into account the political orientations of the president and senators who participated in the judge's appointment and it has been shown to be a more accurate measure of judicial politics than the political party of the appointing president alone (Giles, Hettinger, and Peppers 2001). Since higher scores indicate greater conservatism, we call this measure judicial conservatism. To explore whether the relationship between deference and case outcome differs across the political spectrum, we also include an interaction effect between judicial conservatism and judicial deference.

8. Judicial opinions often refer to multiple structures and we sum the number of structures in each category. As a robustness check, we ran separate analyses in which we replaced these sums with dichotomous variables indicating whether the opinion included any structures in each category. All results remained statistically significant and in the same direction.

9. The Giles, Hettinger, and Peppers method uses common space scores, based on senators' and presidents' political orientations based on their voting records (Poole and Rosenthal 1997; Poole 1998). When both senators share the president's party affiliation, the judge's score is the average of the senators' common space scores. When only one senator shares the president's party affiliation, the judge is assigned the common space score of that senator. When neither senator shares the president's party affiliation, the judge is assigned the president's common space score. Micheal Giles kindly provided data on circuit court judges' political orientations, as well as his algorithm, which we used to calculate common space scores for district court judges using data from the National Judicial Center. In cases with multiple judges, we use the average score. This measure ranges from -1 (most liberal) to +1 (most conservative). 


\section{Control Variables}

Our analyses include several sets of control variables. First, we control for various plaintiff characteristics. We include variables indicating female plaintiffs, nonwhite plaintiffs, and plaintiffs whose race or sex is not mentioned in the opinion (white males are the omitted category). Because Best et al. (2011) found a significant interaction between race and sex in predicting case outcome, we also include a variable for nonwhite female plaintiffs. We control for plaintiffs' occupational prestige using 1980 Census occupational categories and the 1989 General Social Survey (GSS) occupational prestige scale (Nakao and Treas 1992). We include a dummy variable indicating plaintiffs whose occupation was not mentioned in the opinion; their prestige scores are set to the mean. We also include variables for the plaintiffs' organizational backing: class action lawsuits, the involvement of governmental or public interest organizations as plaintiffs or amici, and union membership.

In addition, we control for several characteristics of the court, procedural posture, legal theories, and claims. We distinguish between district court cases, circuit court cases in which the employer prevailed in the district court, and circuit court cases in which the employee achieved at least a partial victory in the circuit court. We also include variables indicating whether the opinion results from a motion to dismiss or from an employer's motion for summary judgment; whether the case involved disparate impact, disparate treatment, and/or hostile work environment theory; and whether the plaintiffs made intersectional claims alleging discrimination based on more than one aspect of their identities (Best et al. 2011). Finally, since plaintiff win rates have declined over time, we control for year. ${ }^{10}$ Table 1 presents descriptive statistics for all variables used in the analysis.

\section{Method of Analysis}

We use logistic regression to analyze the relationship between case outcome and our independent variables. Our results were very robust to model specification; our findings were substantively unchanged when using generalized ordered logistic regressions of a three-category dependent variable and when including random effects for judges (see Appendix 1).

\section{RESULTS}

Table 2 presents the results of a nested set of models exploring the determinants of case outcome. Positive coefficients indicate increased likelihood that plaintiffs will achieve at least a partial victory; negative coefficients indicate increased likelihood of complete defendant victory.

10. Our findings were very similar when using year fixed effects instead of a linear year variable (see Appendix 1). 
TABLE 1.

Descriptive Statistics

\begin{tabular}{|c|c|c|c|}
\hline & Mean $/ \%$ & SD & Range \\
\hline At least partial plaintiff victory & $43 \%$ & & \\
\hline \multicolumn{4}{|l|}{ Number of structures } \\
\hline Deferred to & 0.40 & 0.84 & {$[0,7]$} \\
\hline Scrutinized, deemed adequate & 0.22 & 0.64 & {$[0,5]$} \\
\hline Scrutinized, deemed inadequate & 0.20 & 0.63 & {$[0,5]$} \\
\hline Judicial conservatism & 0.02 & 0.32 & {$[-.63, .66]$} \\
\hline \multicolumn{4}{|l|}{ Plaintiff's gender } \\
\hline Male & $44 \%$ & & \\
\hline Female & $46 \%$ & & \\
\hline Sex unknown & $9.6 \%$ & & \\
\hline \multicolumn{4}{|l|}{ Plaintiff's race } \\
\hline White & $6 \%$ & & \\
\hline Nonwhite & $34 \%$ & & \\
\hline Race unknown & $60 \%$ & & \\
\hline \multicolumn{4}{|l|}{ Other plaintiff characteristics } \\
\hline Occupational prestige & 47 & 13 & {$[17,99]$} \\
\hline Prestige missing & $22 \%$ & & \\
\hline Class action & $8.9 \%$ & & \\
\hline $\begin{array}{l}\text { Government agency or public interest law } \\
\text { firm as plaintiff or amicus }\end{array}$ & $9.2 \%$ & & \\
\hline Union member & $16 \%$ & & \\
\hline \multicolumn{4}{|l|}{ Court, history, and procedural posture } \\
\hline District court & $67 \%$ & & \\
\hline Circuit court, employer won in lower court & $26 \%$ & & \\
\hline Circuit court, employee won in lower court & $7.6 \%$ & & \\
\hline Motion to dismiss & $5.4 \%$ & & \\
\hline Summary judgment (employer's motion) & $51 \%$ & & \\
\hline \multicolumn{4}{|l|}{ Legal theories and claims } \\
\hline Disparate impact & $13 \%$ & & \\
\hline Disparate treatment & $85 \%$ & & . \\
\hline Hostile work environment & $15 \%$ & & \\
\hline Intersectional claim & $17 \%$ & & \\
\hline Year & 1990 & 7.5 & {$[1967,1999]$} \\
\hline
\end{tabular}

Model 1 (Table 2) is the baseline model, including only the control variables. Not surprisingly, given that appellate judges are deferential to lower courts, plaintiffs were more likely to win circuit court cases if they had won in the lower courts and less likely to win circuit court cases if they had lost in the lower courts. Consistent with prior research (Nielsen, Nelson, and Lancaster 2010; Best et al. 2011), plaintiffs with more organizational resources-those organized into class actions or represented by the government or a public interest law firm-were more likely to prevail. Plaintiffs also fared well in opinions resulting from a motion to dismiss. We also found a positive effect for female plaintiffs, but a larger negative interaction effect for nonwhite female plaintiffs, indicating that all else equal, white women were more likely to prevail than white men, but nonwhite women fared worse than 
TABLE 2.

Logistic Regressions of Plaintiff Victory on Structures and Judicial Politics ${ }^{a}$

\begin{tabular}{|c|c|c|c|c|c|}
\hline & (1) & $(2)$ & (3) & (4) & $(5)^{\mathrm{c}}$ \\
\hline \multicolumn{6}{|l|}{ Number of structures } \\
\hline Deferred to & & $\begin{array}{c}-1.10 * * * \\
(0.16)\end{array}$ & $\begin{array}{c}-1.11^{* * *} \\
(0.16)\end{array}$ & $\begin{array}{c}-1.16^{* * *} \\
(0.17)\end{array}$ & $\begin{array}{c}-1.18^{* * *} \\
(0.24)\end{array}$ \\
\hline Scrutinized, deemed adequate & & $\begin{array}{c}-1.19 * * * \\
(0.25)\end{array}$ & $\begin{array}{c}-1.19 * * * \\
(0.25)\end{array}$ & $\begin{array}{c}-1.21 * * * \\
(0.25)\end{array}$ & $\begin{array}{c}-0.75^{*} \\
(0.35)\end{array}$ \\
\hline Scrutinized, deemed inadequate & & $\begin{array}{c}4.23 * * * \\
(0.63)\end{array}$ & $\begin{array}{c}4.24 * * * \\
(0.63)\end{array}$ & $\begin{array}{c}4.17^{* * *} \\
(0.63)\end{array}$ & $\begin{array}{c}3.39 * * * \\
(0.78)\end{array}$ \\
\hline Judicial conservatism & & & $\begin{array}{c}-0.39 \\
(0.25)\end{array}$ & $\begin{array}{c}-0.63^{*} \\
(0.27)\end{array}$ & $\begin{array}{l}-1.00^{*} \\
(0.41)\end{array}$ \\
\hline Conservatism $\times$ deference & & & & $\begin{array}{l}0.91^{*} \\
(0.43)\end{array}$ & $\begin{array}{c}1.05 \\
(0.60)\end{array}$ \\
\hline \multicolumn{6}{|l|}{ Plaintiff characteristics } \\
\hline Female & $\begin{array}{c}0.34 \\
(0.19)\end{array}$ & $\begin{array}{c}0.58^{* *} \\
(0.22)\end{array}$ & $\begin{array}{l}0.58^{* * *} \\
(0.22)\end{array}$ & $\begin{array}{l}0.59 * * \\
(0.22)\end{array}$ & $\begin{array}{c}0.45 \\
(0.32)\end{array}$ \\
\hline Sex unknown & $\begin{array}{l}0.92 * * \\
(0.31)\end{array}$ & $\begin{array}{l}1.17^{* *} \\
(0.37)\end{array}$ & $\begin{array}{l}1.15^{* *} \\
(0.37)\end{array}$ & $\begin{array}{l}1.12 * * \\
(0.37)\end{array}$ & $\begin{array}{c}0.96 \\
(0.79)\end{array}$ \\
\hline \multicolumn{6}{|l|}{ (Male-omitted category) } \\
\hline Nonwhite & $\begin{array}{l}-0.22 \\
(0.33)\end{array}$ & $\begin{array}{l}0.0051 \\
(0.40)\end{array}$ & $\begin{array}{l}0.029 \\
(0.41)\end{array}$ & $\begin{array}{c}0.018 \\
(0.41)\end{array}$ & $\begin{array}{l}-0.40 \\
(0.57)\end{array}$ \\
\hline Race unknown & $\begin{array}{l}-0.24 \\
(0.30)\end{array}$ & $\begin{array}{r}-0.066 \\
(0.37)\end{array}$ & $\begin{array}{l}-0.075 \\
(0.37)\end{array}$ & $\begin{array}{r}-0.087 \\
(0.37)\end{array}$ & $\begin{array}{l}-0.56 \\
(0.52)\end{array}$ \\
\hline \multicolumn{6}{|l|}{ (White—omitted category) } \\
\hline Nonwhite female & $\begin{array}{l}-0.52 \\
(0.32)\end{array}$ & $\begin{array}{c}-0.97^{*} \\
(0.40)\end{array}$ & $\begin{array}{l}-0.96^{*} \\
(0.40)\end{array}$ & $\begin{array}{c}-0.98^{*} \\
(0.40)\end{array}$ & $\begin{array}{c}-0.69 \\
(0.57)\end{array}$ \\
\hline Occupational prestige & $\begin{array}{c}0.0023 \\
(0.0055)\end{array}$ & $\begin{array}{c}0.0029 \\
(0.0070)\end{array}$ & $\begin{array}{c}0.0026 \\
(0.0070)\end{array}$ & $\begin{array}{c}0.0030 \\
(0.0071)\end{array}$ & $\begin{array}{c}-0.0053 \\
(0.010)\end{array}$ \\
\hline Prestige missing & $\begin{array}{c}-0.29 \\
(0.19)\end{array}$ & $\begin{array}{c}-0.65^{* *} \\
(0.22)\end{array}$ & $\begin{array}{c}-0.62 * * \\
(0.22)\end{array}$ & $\begin{array}{c}-0.60 * * \\
(0.22)\end{array}$ & $\begin{array}{c}-0.77^{*} \\
(0.37)\end{array}$ \\
\hline Class action & $\begin{array}{l}1.06^{* *} \\
(0.34)\end{array}$ & $\begin{array}{c}1.39 * * * \\
(0.40)\end{array}$ & $\begin{array}{c}1.41^{* * *} \\
(0.41)\end{array}$ & $\begin{array}{l}1.32 * * \\
(0.40)\end{array}$ & $\begin{array}{l}0.047 \\
(1.68)\end{array}$ \\
\hline \multirow[t]{2}{*}{$\begin{array}{l}\text { Gov't/public interest } \\
\text { plaintiff or amicus }\end{array}$} & $0.72 * *$ & 0.53 & 0.53 & 0.51 & 1.17 \\
\hline & $(0.28)$ & $(0.34)$ & $(0.34)$ & $(0.34)$ & $(0.86)$ \\
\hline Union member & $\begin{array}{l}-0.29 \\
(0.20)\end{array}$ & $\begin{array}{l}-0.21 \\
(0.24)\end{array}$ & $\begin{array}{l}-0.22 \\
(0.24)\end{array}$ & $\begin{array}{l}-0.19 \\
(0.24)\end{array}$ & $\begin{array}{l}-0.72 \\
(0.40)\end{array}$ \\
\hline \multicolumn{6}{|c|}{ Court, history, and procedural posture } \\
\hline Circuit; employer won in district & $\begin{array}{c}-0.97^{* * *} \\
(0.18)\end{array}$ & $\begin{array}{c}-1.49^{* * *} \\
(0.24)\end{array}$ & $\begin{array}{c}-1.49 * * * \\
(0.24)\end{array}$ & $\begin{array}{c}-1.49 * * * \\
(0.24)\end{array}$ & $\begin{array}{c}-1.68^{* * *} \\
(0.36)\end{array}$ \\
\hline Circuit; employee won in district & $\begin{array}{c}0.99 * * \\
(0.31)\end{array}$ & $\begin{array}{c}0.36 \\
(0.43)\end{array}$ & $\begin{array}{c}0.37 \\
(0.43)\end{array}$ & $\begin{array}{c}0.38 \\
(0.43)\end{array}$ & \\
\hline \multicolumn{6}{|l|}{ (District court—omitted category) } \\
\hline Motion to dismiss & $\begin{array}{l}1.06^{* *} \\
(0.33)\end{array}$ & $\begin{array}{l}1.05 * * \\
(0.36)\end{array}$ & $\begin{array}{l}1.06^{* *} \\
(0.36)\end{array}$ & $\begin{array}{l}1.08^{* *} \\
(0.36)\end{array}$ & \\
\hline $\begin{array}{l}\text { Summary judgment } \\
\text { (employer's motion) }\end{array}$ & -0.0038 & 0.24 & 0.25 & 0.26 & \\
\hline
\end{tabular}


Table 2. Continued

\begin{tabular}{lccccc}
\hline & $(1)$ & $(2)$ & $(3)$ & $(4)$ & $(5)^{\mathbf{c}}$ \\
\hline Legal theories and claims & & & & & \\
$\quad$ Disparate impact & -0.18 & -0.30 & -0.29 & -0.27 & 0.077 \\
& $(0.25)$ & $(0.30)$ & $(0.30)$ & $(0.30)$ & $(0.54)$ \\
Disparate treatment & -0.15 & -0.16 & -0.16 & -0.17 & \\
& $(0.22)$ & $(0.27)$ & $(0.27)$ & $(0.27)$ & \\
Hostile work environment & 0.15 & 0.21 & 0.19 & 0.18 & 0.37 \\
& $(0.21)$ & $(0.25)$ & $(0.25)$ & $(0.25)$ & $(0.38)$ \\
Intersectional claim & -0.32 & -0.23 & -0.23 & -0.21 & -0.12 \\
& $(0.20)$ & $(0.25)$ & $(0.25)$ & $(0.25)$ & $(0.33)$ \\
Year & -0.014 & -0.023 & -0.021 & -0.022 & $-0.060^{*}$ \\
& $(0.012)$ & $(0.014)$ & $(0.014)$ & $(0.014)$ & $(0.025)$ \\
Constant & 27.5 & 45.1 & 42.5 & 42.7 & $120^{*}$ \\
& $(23.5)$ & $(27.8)$ & $(27.9)$ & $(28.0)$ & $(50.5)$ \\
Incremental chi ${ }^{2}$ test & & $319 * * *$ & 2.47 & $4.58^{*}$ & \\
Degrees of freedom $^{\mathrm{b}}$ & & 3 & 1 & 1 & \\
${\text { Pseudo- }{ }^{2}}^{2}$ & 0.119 & 0.356 & 0.357 & 0.361 & .297 \\
Observations & 989 & 989 & 989 & 989 & 450 \\
\hline
\end{tabular}

\footnotetext{
${ }^{a}$ The dependent variable is equal to 1 when the plaintiff achieved at least a partial victory.

${ }^{b}$ The incremental $\mathrm{chi}^{2}$ tests compare each model to that in the previous column. These results are only shown for nested models.

'Model 5 limits the sample to adjudications of employers' motions for summary judgment in disparate treatment cases.

${ }^{* * *} p<0.001,{ }^{* *} p<0.01,{ }^{*} p<0.05$ (two-tailed tests).

Standard errors are in parentheses.
}

nonwhite men. These race and gender effects, explored in detail in Best et al. (2011), only become statistically significant with the inclusion of additional variables in Models 2 through 4 . None of the legal theories or claims was significantly associated with plaintiff victory. Plaintiff win rates have declined over the years, but this time pattern was statistically significant only in Model 5, which limits the sample to adjudications of employers' motions for summary judgment in cases involving disparate treatment.

Model 2 (Table 2) shows that judicial deference is strongly associated with employer victory. This model includes counts of the number of structures judges deferred to, along with controls for the number of structures judges scrutinized and deemed either adequate or inadequate. Including these measures of judicial reasoning substantially improves the fit of the models. Unsurprisingly, when judges scrutinize the efficacy of structures and find them adequate, employers are more likely to prevail, and when structures are found inadequate, plaintiffs are more likely to secure at least a partial victory. However, employers are also at an advantage when judges defer to structures-that is, when judges deem structures relevant to the question of whether discrimination occurred but fail to scrutinize their effectiveness. Strikingly, it is almost as harmful for plaintiffs when judges defer to a structure as when they conclude that a structure is adequate. Further, judges defer to almost twice as many structures as they scrutinize and find adequate, suggesting that, in practice, deference has a much larger effect on case outcome than does scrutiny. 


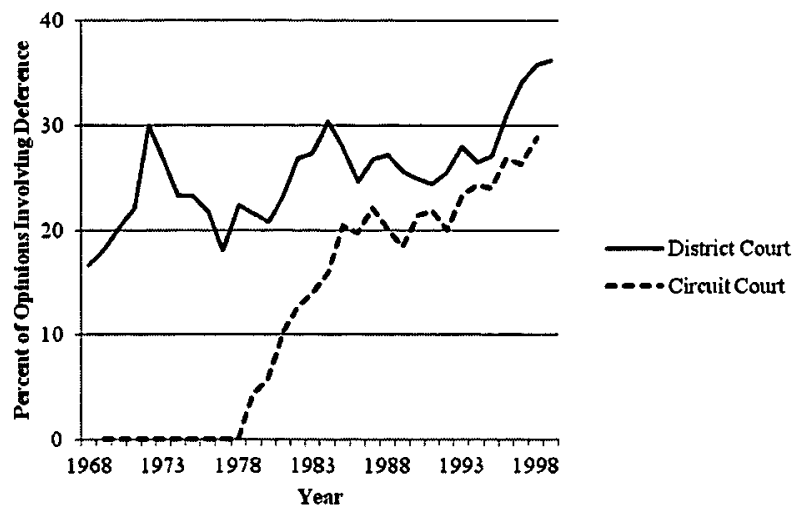

\section{FIGURE 1.}

Percent of Opinions Involving Judicial Deference ${ }^{a}$ Over Time

${ }^{\mathrm{a}}$ Cases are coded as involving judicial deference when, for at least one structure deemed relevant to the question of whether discrimination has occurred, the court (1) never considers adequacy, (2) pays lip service to adequacy, or (3) states that inadequacy does not matter. The graph shows seven-year moving averages.

These results are especially troubling because judges have become increasingly likely to defer to organizational structures over time (Edelman et al. 2011). Figure 1 shows the increase over time in the proportion of cases that involve judicial deference to at least one structure. In the district courts, deference occurred in 20 percent to 30 percent of opinions in the 1970s and 1980s and in over 35 percent by 1999. The increase in deference was more dramatic in the circuit courts, where we observed no deference before 1980 and then an increase to almost 30 percent of cases by the mid-1990s (see Figure 1). ${ }^{11}$

Model 3 (Table 2) adds a measure of judicial conservatism. All else equal, more conservative judges are less likely to rule in favor of plaintiffs, although this pattern is not statistically significant. Given that our data come predominantly from the district courts where judicial ideology has been found to matter less than in higher courts, the lack of significance is not surprising (Pinello 1999).

Nonetheless, if judicial deference only appeared to be related to case outcome because conservative judges were looking for an excuse to rule against employees, the inclusion of this variable should diminish the deference coefficient. Instead, the inclusion of this measure of judicial ideology has no effect on the deference coefficient. This pattern indicates that the deference effect is not merely masking the effects of judicial politics. The deference coefficient is also robust to the inclusion of judge fixed effects (see Appendix 1). That is, even when comparing opinions written by the same judge, plaintiffs are less likely to prevail in decisions involving deference. Thus, neither judicial politics nor any other stable characteristic of judges can explain away the relationship between deference and case outcome.

11. Both deference and employer victory have become more frequent over the years, making it especially important to control for the passage of time to ensure that the correlation is not spurious. The models presented in Table 2 include only a linear year variable, but the results are robust to the inclusion of year fixed effects (see Appendix 1). 


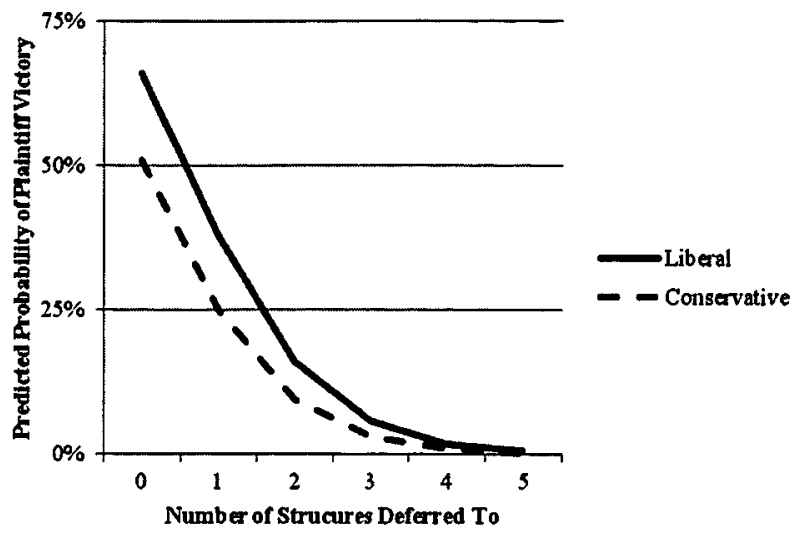

FIGURE 2.

Predicted Case Outcome by Judicial Politics and Deference ${ }^{a}$

aredicted probabilities of at least partial plaintiff victory from Model 4 (Table A1), with controls held constant at their means. Probabilities were calculated for judges with common space scores of -.5 (liberal) and .5 (conservative). The empirically observed common space scores in our sample ranged from -.63 to .66 .

Interestingly, however, judicial politics and judicial deference are related in a more subtle way to case outcome. Model 4 (Table 2) includes an interaction effect for judicial conservatism and judicial deference. The interaction coefficient measures whether deference operates similarly for liberal and conservative judges. While the main effects of deference and conservatism are negative, the interaction effect is significant and positive, suggesting that deference has a smaller effect for conservative judges than for liberal judges. To illustrate this pattern, Figure 2 shows the predicted probabilities of plaintiff victory when liberal and conservative judges defer to varying numbers of structures. On average, plaintiffs fare better in opinions written by liberal judges. However, as judges defer to more structures, this advantage disappears. Although liberal judges generally favor plaintiffs more than do conservative judges, liberal judges who defer to organizational structures look more like conservative judges.

Finally, we explore whether deference and case outcome are still related in situations when judges are extremely unlikely to defer to structures purposefully or strategically to justify a predetermined outcome. Model 5 (Table 2) limits the sample to opinions resulting from an employer's motion for summary judgment in cases involving disparate treatment. ${ }^{12}$ When ruling on an employer's motion for summary judgment, judges are legally prohibited from drawing inferences against the employee (Anderson ข. Liberty Lobby 1986; Reeves ข. Sanderson Plumbing Products 2000). In disparate treatment cases, deference to organizational structures requires

12. By necessity, Model 5 omits variables that no longer vary within the limited sample: disparate treatment, summary judgment, circuit court cases in which the employee won in the district court, and motion to dismiss. Cases involving disparate treatment can also involve other legal theories; therefore, the variables indicating disparate impact and hostile work environment are still included in Model 5. 
the drawing of inferences in favor of the employer. If judicial deference were primarily a conscious attempt to justify a decision that had already been teached, we would not expect it to occur in these opinions, or to be related to their outcome. However, limiting the sample to these opinions does not change the size or significance of the deference coefficient, which suggests that judicial deference is not primarily a matter of conscious strategy by judges.

\section{DISCUSSION AND IMPLICATIONS}

Earlier research on law and organizations showed that in the decades following the passage of EEO laws, employers developed a series of structures that came to be associated with rationality and legal compliance (Edelman 1992; Sutton et al. 1994; Sutton and Dobbin 1996; Dobbin and Sutton 1998; Edelman and Petterson 1999; Edelman, Uggen, and Erlander 1999). Although some structures, such as affirmative action plans that utilize goals and timetables for minority inclusion, are effective in reducing inequality (Kalev, Dobbin, and Kelly 2006), many are merely symbolic, doing little or nothing to prevent or ameliorate discrimination in the workplace (Baron, Mitmann, and Newman 1991; Edelman 1992; Edelman, Erlanger, and Lande 1993; Edelman and Petterson 1999; Kalev, Dobbin, and Kelly 2006). Therefore, when employers introduce structures as evidence of nondiscrimination, judges should consider whether the particular structures are adequate, even-handedly applied, and effective in preventing discrimination. Yet Edelman et al. (2011) showed that, over time, judges have become more likely to defer to organizational structures, that is, to use them to infer nondiscrimination without scrutinizing their adequacy.

The current study shows that judicial deference matters for case outcome, over and above the effect of judicial ideology. When judges do consider the adequacy of organizational structures, the result is what might be predicted: if judges find the structures adequate, the employer usually wins. Conversely, if judges find the structures inadequate, plaintiffs are more likely to win. Our results show that when judges defer to organizational structures-treating their mere presence as evidence of nondiscrimination while failing to scrutinize their effectiveness-employers benefit.

Troublingly, organizations can win cases when they have antidiscrimination policies that exist on the books but are not followed in practice, when they have diversity training programs that do not result in greater diversity or better treatment of minorities and women, when they have grievance procedures that employees are afraid to use, and when they have formalized personnel policies that are used post hoc to justify discriminatory decisions. These findings are especially concerning when viewed in light of the fact that judicial deference is increasing over time (Edelman et al. 2011) and was occurring in fully a third of all EEO opinions by the end of the twentieth century. The rise of judicial deference helps explain why it is becoming easier for employers to prevail in civil rights cases.

In addition to demonstrating the impact of judicial deference on case outcome, we document an interaction between judicial conservatism and deference that suggests a new way of thinking about the role of judicial ideology. Whereas much 
work in political science has shown that ideology predicts case outcome (Segal and Cover 1989; Baum 1992; Segal and Spaeth 1993, 1996, 2002; Spaeth and Segal 1999), our results show that, counterintuitively, liberal judges who defer to institutionalized organizational structures decide cases more like conservative judges. Our results support the possibility that liberal judges may be more impressed by the trappings of due process than are conservative judges (Edelman et al. 2011) and that this pattern of legal reasoning can overshadow their pro-plaintiff inclinations. Thus, the effects of judicial politics are subtler than a simple bias in either direction.

Because our data come from written opinions, we cannot directly observe judges' reasoning processes. We therefore cannot determine whether deferring to structures caused judges to rule in favor of defendants or whether, having decided to rule for the defendant, judges invoke the presence of structures to legitimize a decision made on other grounds. However, two patterns in our data suggest that the strategic use of structures to justify decisions cannot fully explain the relationship between deference and case outcome. First, the deference effect remains large and statistically significant even when controlling for judicial conservatism, suggesting that the effect of deference is not merely an artifact of conservative judges using the presence of structures to justify predetermined decisions against plaintiffs. In fact, the effects of deference are strongest for liberal judges, who tend to view plaintiffs more favorably.

Second, as we showed in Model 5 (Table 2), judicial deference is associated with employer victory even when we limit the sample to opinions resulting from employers' motions for summary adjudications in disparate treatment cases, in which adjudications judges are not permitted to draw inferences in favor of the moving party employer. This finding indicates that, whether mindfully or not, if a judge uses the presence of a formal structure as evidence of nondiscrimination without scrutinizing its ability to eliminate discrimination, that judge is necessarily using the structure inferentially, along following syllogistic lines:

$P_{(M)}$ Employers who utilize formal employment structures are rational and fair and would not discriminate;

$P_{(m)}$ This employer utilizes formal employment structures;

$C$ Therefore, this employer is rational and fair and would not discriminate.

At least since the 1970 s, courts have presumed that nondiscrimination is the norm in the business world and, conversely, that discrimination is aberrant (Krieger 1995, 1998; Krieger and Fiske 2006). In this view, discrimination occurs only when employers or their agents do something that is wrong, unprofessional, and irrational. This presumption is illustrated throughout antidiscrimination case law. One can observe it as early as 1978, in the Supreme Court's decision in Furnco Construction Company $v$. Waters where the Court opined:

[W] know from our experience that more often than not people do not act in a totally arbitrary manner, without any underlying reasons, especially in a business setting. Thus, when all legitimate reasons for rejecting an applicant have been eliminated as possible reasons for the employer's 
actions, it is more likely than not the employer, who we generally assume acts only with some reason, based his decision on an impermissible consideration such as race. $(1978,577)$

The implicit assumption that discrimination is aberrant and occurs only when an employer is not acting rationally may lead courts to look for signs or symptoms of employer legitimacy or rationality. If only allegedly irrational employers discriminate, and if allegedly rational employers adopt institutionalized structures, then evidence of the presence of those structures supports an inference of rationality, which in turn supports an inference of nondiscrimination.

If we assume that judges-particularly district court judges, who are most vulnerable to reversal on appeal-attempt to comply with the legal standards governing summary judgment, including the prohibition against drawing inferences against a nonmoving party plaintiff/employee, it follows that when they defer to institutionalized structures, judges are unaware that they are drawing an inference at all. It seems unlikely that a judge-especially a district court judge-would deliberately draw inferences against a nonmoving party, in direct contravention of controlling Supreme Court authority, to veil a pro-employer decision reached on other grounds. It makes much more sense to conclude that judicial deference to institutionalized employment practices operates as some kind of System 1 heuristic that can be overridden only through subsequent deliberate, effortful, motivated mental processing (Guthrie, Rachlinski, and Wistrich 2001, 2002, 2007). In this respect, our results are consistent with the intuitive override model of judging posited by Guthrie, Rachlinski, and Wistrich (2007).

Because judicial deference is not limited to conservative judges and favors employers, even in summary adjudications in disparate treatment cases, we think that much of the time, judicial deference may result from a type of priming effect (Gilbert 1989; Gilbert and Malone 1995; Brest and Krieger 2010). As judges, like other legal and organizational actors, come to view institutionalized employment structures and practices as reliable signals of organizational rationality, fairness, and attention to legal norms, the presence of those structures in a case primes conceptions of organizational rationality, fairness, and good governance, making an inference of organizational fairness and rationality (and therefore nondiscrimination) not only more likely, but also less recognizable as a type of inferential reasoning at all. In this way, the presence of institutionalized employment practices, functioning as signals of organizational rationality and fairness, may bias judicial reasoning and systematically skew spontaneous attributions of employer motivation (Krieger 1998; Krieger and Fiske 2006).

Significantly, our findings are consistent with experimental results reported by Kaiser et al. (2013), which demonstrated that the presence of diversity structures in descriptions of hypothetical organizations caused high-status group members (i.e., whites and males) to view those organizations as being procedurally fair environments for minorities and women, even in the face of facts indicating that minorities and women had been disadvantaged within them. The presence of these structures, Kaiser and her collaborators suggest, creates an illusion of fairness in the treatment of women and minorities, which leads high-status individuals to underperceive 
discrimination against them and to decrease sympathy toward them when they claim discrimination (Kaiser et al. 2013). Our findings suggest that judges may be among those high-status individuals for whom the presence of diversity structures creates an illusion of fairness that reduces plaintiffs' chances of success in EEO litigation, even in the face of substantial evidence indicating that discrimination has occurred.

Importantly, however, establishing a causal effect between deference and case outcome is not essential to our argument. Irrespective of the direction of causation, the association between judicial deference and case outcome supports legal endogeneity theory. This association demonstrates that judicial outcomes are influenced by managerialized conceptions of law that treat institutionalized organizational structures as indicative, or even constitutive, of compliance. Regardless of the reasoning process that produces it, moreover, a body of precedential opinions in which judges defer to structures and employers prevail reinforces employers' beliefs that ineffective structures will shield them from discrimination. No matter which way the causal arrow points, the link between judicial deference and employer victory reinforces the cycle of ineffective, symbolic responses to discrimination. In this regard, judicial deference consistently favors the "haves" over the "have-nots" in the employment context and is thus an important mechanism through which even laws designed to protect the have-nots exacerbate patterns of social stratification.

The relationship between judicial deference and case outcome also has important implications for social policy. Below, we outline separately the implications for judges, lawyers, and policy makers.

\section{Implications for Judges}

Our results build on the findings of other researchers indicating that judges, like laypeople, are susceptible to various cognitive biases and heuristics that can systematically bias their judgment (Guthrie, Rachlinski, and Wistrich 2001, 2007; Wistrich, Guthrie, and Rachlinski 2005; Rachlinski et al. 2009). Judicial deference can be understood as a problematic form of implicit judicial cognition that is shaped by institutionalized practices and their taken-for-granted social meanings. When judges defer, they draw inferences of nondiscrimination from the mere presence of structures, the adequacy or effectiveness of which they have ignored, papered over, or dismissed as legally irrelevant.

Judges should consciously guard against using the presence of institutionalized employment practices to infer discrimination without careful scrutiny of the quality of those structures. Spontaneous attributions of fairness in response to institutionalized organizational structures can be controlled through a deliberative process that corrects the intuitively biased initial judgment (Guthrie, Rachlinski, and Wistrich 2007; Rachlinski et al. 2009), but for that correction to occur, judges must be aware that they need to monitor their judgments for the effects of cognitive biases and heuristics, and they must have the time, motivation, and information needed to do so (Rachlinski et al. 2009). Judges need to understand that the mere presence of institutionalized employment structures and practices may predispose them to view 
an employer as rational, fair, and compliance oriented and that this, in turn, may cause them to underidentify the effects of discrimination, particularly in its more subtle forms, on employer decision making. To maximize adjudicative accuracy, judges must scrutinize the quality of an employer's structures and practices, and this requires that plaintiffs be given the opportunity to develop and present facts relevant to this inquiry for the court's consideration.

Accordingly, in managing discovery and in adjudicating discovery disputes, judges must ensure that plaintiffs are afforded ample opportunity to take discovery and present evidence on the quality and effectiveness of any organizational compliance structures involved in the case. This is particularly important because substantial research has shown that many of the structures to which judges are deferring are ineffective in advancing nondiscrimination goals (Kalev and Dobbin 2006; Kalev, Dobbin, and Kelly 2006).

As importantly, judges must be mindful that the heuristic use of institutionalized employment practices as indicia of nondiscrimination involves inferential reasoning that favors employers. For this reason, judges should be particularly vigilant about avoiding unwitting deference to institutionalized employment practices in summary adjudication contexts or on appeal under a substantial evidence standard of review.

Judges should be made aware, through judicial training and effective advocacy by plaintiffs' and government attorneys, that institutionalized employment structures do not in and of themselves prevent discrimination and that the presence of these structures should not be used heuristically to infer nondiscrimination, particularly in summary adjudication contexts. Judges should consider the possibility that even the mere reference to these structures may implicitly prime constructs of employer rationality, fairness, and compliance orientation and that this priming effect may in turn bias their judgments about whether discrimination has occurred. Plaintiffs' lawyers have a large role to play in assuring that the necessary de-biasing occurs.

\section{Implications for Plaintiffs' Lawyers}

Although, ultimately, it is judges who either do or do not infer nondiscrimination from the mere presence of organizational structures, plaintiffs' attorneys may play a role in this process by succeeding or failing to draw judicial attention to inadequacies in employers' structures. To counter the judicial tendency to use these structures inferentially, particularly in procedurally inappropriate contexts, plaintiffs' lawyers must deploy sufficient discovery and advocacy resources to uncover and draw judicial attention to inadequacies in employers' structures. Plaintiffs' attorneys should also emphasize that by inferring fair treatment from organizational structures without adequate scrutiny, judges are inappropriately drawing inferences in favor of the moving party in connection with motions for summary judgment, motions for judgment as a matter of law, appeals of rulings on those motions, and on reviews of jury verdicts under a substantial evidence standard of review, none of which is permissible under applicable federal trial and appellate procedural rules.

Experienced lawyers representing sexual harassment plaintiffs know that to prevail, they must demonstrate that an employer's antiharassment structures, such as 
antiharassment policies, grievance procedures, and training programs, are inadequate to prevent harassment from occurring or to remedy harassment if it does occur (Grossman 2000, 2003; Bisom-Rapp 2001). Plaintiffs' lawyers also generally know that when an employer policy or practice is itself attacked as illegal, as in a disparate impact case, success turns in part on demonstrating the practice's lack of relatedness to the objectives of EEO law or to the employer's stated business-related goals (Krieger 1995; Jolls 2001). However, many plaintiffs' lawyers are unaware that, even though the substantive law does not make formal policies and practices directly relevant in disparate treatment cases, failure to undermine the "halo effects" (Brest and Krieger 2010) created by institutionalized employment structures can significantly lessen a disparate treatment plaintiff's chances of success, even at the summary judgment stage.

To counter these effects, plaintiffs' lawyers must interrupt judges' heuristic use of structures as markers of employer rationality and fairness and encourage scrutiny of those structures. This can be accomplished in two related ways. First, plaintiffs' lawyers must conduct discovery sufficient to determine whether employers' structures are adequate, either in general or in the context of a particular case, to prevent as opposed to merely mask discrimination (Kalev, Dobbin, and Kelly 2006; Krieger and Fiske 2006). This discovery should illuminate whether, how, and to what effect the structure was applied in other situations, whether the practice was designed and operated to control implicit or other subtle forms of bias, and whether the practice has actually been shown to have any efficacy in advancing EEO goals (Kalev, Dobbin, and Kelly 2006). To the extent that problems are found, these must be made salient to the court.

Second, in employer-filed motions for summary adjudication, plaintiffs' lawyers must be prepared to argue effectively against the inferential use of structures in ways that favor the employer/defendant. In disparate treatment cases, judicial deference is unquestionably a form of judicial inference. From the presence of formal employment policies and practices, judges infer employer rationality, fairmindedness, and attention to legal norms. From employer rationality, fairmindedness, and attentiveness to legal norms, judges infer the employer's disinclination toward discrimination.

Plaintiffs' lawyers must constantly remind district and circuit court judges that the drawing of inferences-even rational ones-is a fact-finder function, inappropriate for a judge deciding a summary judgment motion or motion for judgment as a matter of law (Anderson v. Liberty Lobby 1986; Reeves v. Sanderson Plumbing Products 2000). In addition, plaintiffs' lawyers must remind appellate court judges who are reviewing trial court grants of summary judgment or judgment as a matter of law, or who are reviewing findings of fact after trial under a substantial evidence standard of review, that the drawing of inferences in ways that favor a moving party or an appellant who lost at trial (Krieger 1998; Wald 1998; Krieger and Fiske 2006; Gertner 2012) is prohibited. The heuristic use of institutionalized employment practices to infer an absence of discriminatory intent, particularly where there has been no meaningful scrutiny of the practice's adequacy, represents a kind of movantfavoring inferential reasoning that is prohibited in these procedural contexts. 


\section{Implications for Policy Makers}

Finally, our findings have significant implications for policy makers, including legal scholars who favor new governance approaches, to EEO compliance policy (Sturm 2001; Green 2003, 2005, 2007; Lobel 2004, 2009, 2012). Our findings undermine key assumptions underlying those approaches, particularly the assumption that courts are institutionally equipped to distinguish effectively between actual compliance with EEO norms and the mere presence of cosmetic or symbolic compliance structures (Krawiec 2003).

For law enforcement agencies, such as the EEOC, the Department of Labor's Office of Federal Contract Compliance Programs, and their state equivalents, our findings caution against the promulgation of administrative guidance that urges employers to adopt formal employment policies, practices, or structures without at the same time using tangible metrics to ensure that these policies, practices, and structure do not serve as mere symbolic indicia of compliance lacking any actual effect on advancing equality or preventing discrimination. Similarly, our findings suggest that the establishment of formal policies, practices, or structures as part of a conciliation agreement, settlement, or judicial decree may be less efficacious in preventing future incidents of discrimination than is commonly thought.

In particular, administrative agencies like the EEOC should be wary of new governance approaches to EEO compliance. New governance advocates argue that the best way to eliminate discrimination is not to police discrimination itself, but to provide incentives for organizations to design structures and practices, such as ethical codes of conduct, diversity training programs, and grievance procedures, that are conducive of general legal norms of workplace equality (Sturm 2001; Lobel 2004; Green 2005). Lobel, for example, suggests that courts encourage employers to reduce discrimination by developing internal compliance structures, "including selfadopted equal employment policies, codes, and diversity training programs" (2004, 421). Similarly, Sturm's (2001) structural approach to EEO regulation proposes that courts articulate legal norms and provide incentives for employers to design and adopt mechanisms for complying with these norms. Among the mechanisms she proposes are training programs, internal reporting channels, and other forms of selfmonitoring.

Our findings join a growing chorus of voices questioning the soundness of these new governance approaches to EEO policy. Opponents of the approach (Grossman 2003; Krawiec 2003; Bagenstos 2006) and supportive skeptics (Estlund 2011) point out that courts have so far shown themselves to be either disinclined or ill equipped-or both-to assess the effectiveness of employer-created compliance structures. Our results support these concerns. By 1999, judicial deference to institutionalized employment practices was occurring in one-third of federal EEO cases reported on Westlaw. Not only are federal courts apparently unable to distinguish meaningful from cosmetic compliance (Krawiec 2003), their lack of inclination or capacity systematically and significantly skews the outcome of EEO litigation in employers' favor. These troubling patterns of judicial reasoning demonstrate yet another way that the haves come out ahead. 


\section{REFERENCES}

Albiston, Catherine R. 1999. The Rule of Law and the Litigation Process: The Paradox of Losing by Winning. Law $\mathcal{E}$ Society Review 33 (4):869-910.

Bagenstos, Samuel R. 2006. The Structural Turn and the Limits of Antidiscrimination Law. Califormia Law Review 94 (1):1-47.

Baron, James N., Brian S. Mittman, and Andrew E. Newman. 1991. Targets of Opportunity: Organizational and Environmental Determinants of Gender Integration within the California Civil Service, 1979-1985. American Journal of Sociology 96 (6):1362-1401.

Baum, Lawrence. 1992. Supreme Court Activism and the Constitution. In The Constitution and American Political Development: An Institutional Perspective, ed. Peter F. Nardulli, 150-76. Champaign, IL: University of Illinois Press.

Best, Rachel Kahn, Lauren B. Edelman, Linda Hamilton Krieger, and Scott R. Eliason. 2011. Multiple Disadvantages: An Empirical Test of Intersectionality Theory in EEO Litigation. Law $\mathcal{E}$ Society Review 45 (4):991-1025.

Bisom-Rapp, Susan. 1999. Bulletproofing the Workplace: Symbol and Substance in Employment Discrimination Law Practice. Florida State University Law Review 26:959-1038.

—. 2001. Fixing Watches with Sledgehammers: The Questionable Embrace of Employee Sexual Harassment Training by the Legal Profession. University of Arkansas at Little Rock Law Review 24:147-68.

Blumrosen, Alfred W. 1993. Modern Law: The Law Transmission System and Equal Employment Opportunity. Madison, WI: University of Wisconsin Press.

Brest, Paul, and Linda Hamilton Krieger. 2010. Problem Solving, Decision Making, and Professional Judgment: A Guide for Lawyers and Policymakers. Oxford: Oxford University Press.

Burawoy, Michael. 1979. Manufacturing Consent: Changes in the Labor Process Under Monopoly Capitalism. Chicago, IL: University of Chicago Press.

Chambliss, Elizabeth. 1996. Title VII as a Displacement of Conflict. Temple Political \& Civil Rights Law Review 6:1-54.

Clayton, Cornell W., and Howard Gillman, eds. 1999. Supreme Court Decision-Making: New Institutionalist Approaches. Chicago, IL: University of Chicago Press.

Cross, Frank B., and Emerson H. Tiller. 1998. Judicial Partisanship and Obedience to Legal Doctrine: Whistleblowing on the Federal Courts of Appeals. Yale Law Journal 107 (7):2155-76.

Dobbin, Frank. 2009. Inventing Equal Opportunity. Princeton, NJ: Princeton University Press.

Dobbin, Frank, and John R. Sutton. 1998. The Strength of a Weak State: The Rights Revolution and the Rise of Human Resources Management Divisions. American Joumal of Sociology 104 (2):441-76.

Dobbin, Frank, John R. Sutton, John W. Meyer, and Richard Scott. 1993. Equal Opportunity Law and the Construction of Internal Labor Markets. American Journal of Sociology 99 (2): $396-427$.

Edelman, Lauren B. 1990. Legal Environments and Organizational Governance: The Expansion of Due Process in the American Workplace. American Journal of Sociology 95 (6):1401-40.

— 1992. Legal Ambiguity and Symbolic Structures: Organizational Mediation of Civil Rights Law. American Journal of Sociology 97 (6):1531-76.

2005. Law at Work: The Endogenous Construction of Civil Rights. In Handbook of Employment Discrimination Research: Rights and Realities, ed. Robert L. Nelson and Laura Beth Nielsen, 337-52. New York: Springer.

2007. Overlapping Fields and Constructed Legalities: The Endogeneity of Law. In Private Equity, Corporate Governance, and the Dynamics of Capital Market Regulation, ed. Justin O'Brien, 55-90. London: World Scientific.

Edelman, Lauren B., Howard S. Erlanger, and John Lande. 1993. Internal Dispute Resolution: The Transformation of Civil Rights in the Workplace. Law \& Society Review 27 (3):497534. 
Edelman, Lauren B., Sally Riggs Fuller, and Iona Mara-Drita. 2001. Diversity Rhetoric and the Managerialization of Law. American Joumal of Sociology 106 (6):1589-1641.

Edelman, Lauren B., Linda H. Krieger, Scott R. Eliason, Catherine R. Albiston, and Virginia Mellema. 2011. When Organizations Rule: Judicial Deference to Institutionalized Employ. ment Structures. American Journal of Sociology 117 (3):888-954.

Edelman, Lauren B., and Stephen M. Petterson. 1999. Symbols and Substance in Organizational Response to Civil Rights Law. Research in Social Stratification and Mobility 17:107-38.

Edelman, Lauren B., and Mark C. Suchman. 1999. When the "Haves" Hold Court: Speculations on the Organizational Internalization of Law. Law $\mathcal{E}$ Society Review 33 (4):941-91.

Edelman, Lauren B., Christopher Uggen, and Howard S. Erlanger. 1999. The Endogeneity of Legal Regulation: Grievance Procedures as Rational Myth. American Journal of Sociology 105 (2):406-54.

Edwards, Richard. 1979. Contested Terrain: The Transformation of the Workplace in the Twentieth Century. New York: Basic Books.

Epstein, Lee, and Jack Knight. 1998. The Choices Judges Make. Washington, DC: Congressional Quarterly.

2000. Toward a Strategic Revolution in Judicial Politics: A Look Back, a Look Ahead. Political Research Quarterly 53 (3):625-61.

—. 2013. Reconsidering Judicial Preferences. Annual Review of Political Science 16:11-31.

Epstein, Lee, and Andrew D. Martin. 2010. Does Public Opinion Influence the Supreme Court? Possibly Yes (But We're Not Sure Why). University of Pennsylvania Joumal of Constitutional Law 13:263-81.

Eskridge, William N., Jr. 1991a. Overriding Supreme Court Statutory Interpretation Decisions. Yale Law Journal 101 (2):331-455.

— 1991b. Reneging on History? Playing the Court/Congress/President Civil Rights Game. California Law Review 79 (3):613-84.

Estlund, Cynthia. 2011. Just the Facts: The Case for Workplace Transparency. Stanford Law Review 63 (2):351-407.

Feeley, Malcolm M., and Edward L. Rubin. 1999. Judicial Policy Making and the Modern State: How the Courts Reformed America's Prisons. Cambridge: Cambridge University Press.

Fraidin, Matthew I. 2013. Decision-Making in Dependency Court: Heuristics, Cognitive Biases, and Accountability. Cleveland State Law Review 60:913-74.

Frederick, Shane. 2005. Cognitive Reflection and Decision Making. Joumal of Economic Perspectives 19 (4):25-42.

Galanter, Marc. 1974. Why the Haves Come Out Ahead: Speculations on the Limits of Legal Change. Law $\mathcal{E}$ Society Review 9 (1):95-160.

Gertner, Nancy. 2012. Losers' Rules. Yale Law Journal Online 122:109-23.

Gibson, James L. 1983. From Simplicity to Complexity: The Development of Theory in the Study of Judicial Behavior. Political Behavior 5 (1):7-49.

Gilbert, Daniel T. 1989. Thinking Lightly About Others: Automatic Components of the Social Inference Process. In Unintended Thought, ed. James S. Uleman and John A. Bargh, 189-211 New York: Guilford Press.

Gilbert, Daniel T., and Patrick S. Malone. 1995. The Correspondence Bias. Psychological Bulletin $117(1): 21-38$.

Giles, Micheal W., Virginia A. Hettinger, and Todd Peppers. 2001. Picking Federal Judges: A Note on Policy and Partisan Selection Agendas. Political Research Quarterly 54 (3):623-41.

Gordon, David M., Richard Edwards, and Michael Reich. 1982. Segmented Work, Divided Workers: The Historical Transformation of Labor in the United States. Cambridge: Cambridge University Press.

Green, Tristin K. 2003. Discrimination in Workplace Dynamics: Toward a Structural Account of Disparate Treatment Theory. Harvard Civil Rights-Civil Liberties Law Review 38:91-157. 2005. Work Culture and Discrimination. Califormia Law Review 93 (3):623-84. 2007. A Structural Approach as Antidiscrimination Mandate: Locating Employer Wrong. Vanderbilt Law Review 60 (3):849-904. 
Grossman, Joanna L. 2000. The First Bite Is Free: Employer Liability for Sexual Harassment. University of Pittsburgh Law Review 61:671-740.

- 2003. The Culture of Compliance: The Final Triumph of Form Over Substance in Sexual Harassment Law. Harvard Women's Law Journal 26:3-75.

Gulati, Mitu, Jeffrey J. Rachlinski, and Donald C. Langevoort. 2004. Fraud by Hindsight. Northwestern University Law Review 98:773-825.

Guthrie, Chris, Jeffrey J. Rachlinski, and Andrew J. Wistrich. 2001. Inside the Judicial Mind. Cornell Law Review 86:777-830.

2002. Judging by Heuristic: Cognitive Illusions in Judicial Decision Making. Judicature 86 (1):44-50.

- 2007. Blinking on the Bench: How Judges Decide Cases. Comell Law Review 93:1-43.

Jolls, Christine. 2001. Antidiscrimination and Accommodation. Harvard Law Review 115 (2): 642-99.

Kahneman, Daniel, and Shane Frederick. 2002. Representativeness Revisited: Attribute Substitution in Intuitive Judgment. In Heuristics and Biases: The Psychology of Intuitive Judgment, ed. Thomas Gilovich, Dale Griffin and Daniel Kahneman, 49-81 Cambridge: Cambridge University Press.

Kaiser, Cheryl R., Brenda Major, Ines Jurcevic, Tessa L. Dover, Laura M. Brady, and Jenessa R. Shapiro. 2013. Presumed Fair: Ironic Effects of Organizational Diversity Structures. Joumal of Personality and Social Psychology 104 (3):504-19.

Kalev, Alexandra, and Frank Dobbin. 2006. Enforcement of Civil Rights Law in Private Workplaces: The Effects of Compliance Reviews and Lawsuits Over Time. Law $\mathcal{E}$ Social Inquiry 31 (4):855-903.

Kalev, Alexandra, Frank Dobbin, and Erin Kelly. 2006. Best Practices or Best Guesses? Assessing the Efficacy of Corporate Affirmative Action and Diversity Policies. American Sociological Review 71 (4):589-617.

Kamieniecki, Sheldon. 2006. Corporate America and Environmental Policy: How Often Does Business Get Its Way? Stanford, CA: Stanford University Press.

Kamin, Kim A., and Jeffrey J. Rachlinski. 1995. Ex Post $\neq$ Ex Ante: Determining Liability in Hindsight. Law and Human Behavior 19 (1):89-104.

Kelly, Erin L. 2003. The Strange History of Employer-Sponsored Child Care: Interested Actors, Uncertainty, and the Transformation of Law in Organizational Fields. American Journal of Sociology 109 (3):606-49.

Knight, Jack, and Lee Epstein. 1996. The Norm of Stare Decisis. American Journal of Political Science $40(4): 1018-35$.

Krawiec, Kimberly D. 2003. Cosmetic Compliance and the Failure of Negotiated Governance. Washington University Law Quarterly 81:487-544.

Krieger, Linda Hamilton. 1995. The Content of Our Categories: A Cognitive Bias Approach to Discrimination and Equal Employment Opportunity. Stanford Law Review 47 (6):1161-1248.

- 1998. Civil Rights Perestroika: Intergroup Relations After Affirmative Action. California Law Review 86 (6): 1251-1333.

Krieger, Linda Hamilton. 2007. The Watched Variable Improves: On Eliminating Sex Discrimination in Employment. In Sex Discrimination in the Workplace: Multidisciplinary Perspectives, ed. Faye Crosby, Margaret Stockdale, and S. Ann Ropp, 295-329. New York: Blackwell.

Krieger, Linda Hamilton, and Susan T. Fiske. 2006. Behavioral Realism in Employment Discrimination Law: Implicit Bias and Disparate Treatment. California Law Review 94 (4):997-1062.

Leech, Beth L., Frank R. Baumgartner, Jeffrey M. Berry, Marie Hojnacki, and David C. Kimball. 2002. Organized Interests and Issue Definition in Policy Debates. In Interest Group Politics, ed. Allan J. Cigler and Burdett A. Loomis, 275-92. Washington, DC: CQ Press.

Lobel, Orly. 2004. The Renew Deal: The Fall of Regulation and the Rise of Governance in Contemporary Legal Thought. Minnesota Law Review 89:342-70.

2009. Citizenship, Organizational Citizenship, and the Laws of Overlapping Obligations. California Law Review 97 (2):433-99. 
- 2012. Linking Prevention, Detection, and Whistleblowing: Principles for Designing Effective Reporting Systems. South Texas Law Review 54:37-52.

Marshall, Anna-Maria. 2005. Idle Rights: Employees' Rights Consciousness and the Construction of Sexual Harassment Policies. Law \& Society Review 39 (1):83-124.

Maveety, Nancy. 2003. The Study of Judicial Behavior and the Discipline of Political Science. In The Pioneers of Judicial Behavior, ed. Nancy Maveety, 1-51 Ann Arbor, MI: University of Michigan Press.

McGuire, Kevin T. 2004. The Institutionalization of the U.S. Supreme Court. Political Analysis 12 (2):128-42.

Nakao, Keiko, and Judith Treas. 1992. The 1989 Socioeconomic Index of Occupations: Construction from the 1989 Occupational Prestige Scores. Chicago, IL: National Opinion Research Center.

Nielsen, Laura Beth, Robert L. Nelson, and Ryon Lancaster. 2010. Individual Justice or Collective Legal Mobilization? Employment Discrimination Litigation in the Post Civil Rights United States. Journal of Empirical Legal Studies 7 (2):175-201.

Pinello, Daniel R. 1999. Linking Party to Judicial Ideology in American Courts: A Meta-Analysis. Justice System Joumal 20 (3):219-54.

Poole, Keith T. 1998. Recovering a Basic Space from a Set of Issue Scales. American Journal of Political Science 42 (3):954-93.

Poole, Keith T., and Howard Rosenthal. 1997. Congress: A Political-Economic History of Roll Call Voting. New York: Oxford University Press.

Posner, Richard A. 1993. What Do Judges and Justices Maximize? (The Same Thing Everybody Else Does). Supreme Court Economic Review 3:1-41.

Powers, James. 2014. A Status Quo Bias: Behavioral Economics and the Federal Preliminary Injunction Standard. Texas Law Review 92:1027-51.

Pritchett, C. Herman. 1948. The Roosevelt Court: A Study in Judicial Politics and Values, 19371947. New York Macmillan.

Purcell, Edward A., Jr. 1992. Litigation and Inequality : Federal Diversity Jurisdiction in Industrial America, 1870-1958. Oxford: Oxford University Press.

Quintanilla, Victor D. 2011. Beyond Common Sense: A Social Psychological Study of Iqbal's Effect on Claims of Race Discrimination. Michigan Journal of Race \& Law 17:1-62.

Rachlinski, Jeffrey J. 1998. A Positive Psychological Theory of Judging in Hindsight. University of Chicago Law Review 65:571-625.

2011. Processing Pleadings and the Psychology of Prejudgment. DePaul Law Review 60:41329.

Rachlinski, Jeffrey J., Sheri Lynn Johnson, Andrew J. Wistrich, and Chris Guthrie. 2009. Does Unconscious Racial Bias Affect Trial Judges. Notre Dame Law Review 84 (3):1195-1246.

Rachlinski, Jeffrey J., Andrew J. Wistrich, and Chris Guthrie. 2013. Altering Attention in Adjudication. UCLA Law Review 60 (6):1587-1618.

Ramji-Nogales, Jaya, Andrew I. Schoenholtz, and Philip G. Schrag. 2009. Refugee Roulette: Disparities in Asylum Adjudication and Proposals for Reform. New York: New York University Press.

Revesz, Richard L. 1997. Environmental Regulation, Ideology, and the D.C. Circuit. Virginia Law Review 83 (8):1717-72.

Roethlisberger, F. J., and William J. Dickson. 1939. Management and the Worker. Cambridge, MA: Harvard University Press.

Schneider, Daniel M. 2005. Using the Social Background Model to Explain Who Wins Federal Appellate Tax Decisions: Do Less Traditional Judges Favor the Taxpayer? Virginia Tax Review 25:201-49.

Scott, W. Richard, and Gerald F. Davis. 2007. Organizations and Organizing: Rational, Natural, and Open Systems Perspectives. London: Pearson Prentice Hall.

Segal, Jeffrey A., and Albert D. Cover. 1989. Ideological Values and the Votes of U.S. Supreme Court Justices. American Political Science Review 83 (2):557-65.

Segal, Jeffrey A., and Harold J. Spaeth. 1993. The Supreme Court and the Attitudinal Model. Cambridge: Cambridge University Press. 
- 1996. The Influence of Stare Decisis on the Votes of United States Supreme Court Justices. American Journal of Political Science 40 (4):971-1003.

2002. The Supreme Court and the Attitudinal Model Revisited. Cambridge: Cambridge University Press.

Selznick, Philip. 1949. TVA and the Grass Roots: A Study in the Sociology of Formal Organization. Berkeley, CA: University of California Press.

— 1957. Leadership in Administration: A Sociological Interpretation. New York: Harper \& Row.

Shepherd, Joanna M. 2009. The Influence of Retention Politics on Judges' Voting. Journal of Legal Studies 38 (1):169-206.

Siegelman, Peter, and John J. Donahue. 1990. Studying the Iceberg from its Tip: A Comparison of Published and Unpublished Employment Discrimination Cases. Law $\mathcal{E}$ Society Review 24 (5):1133-70.

Songer, Donald R., and Reginald S. Sheehan. 1993. Interest Group Success in the Courts: Amicus Participation in the Supreme Court. Political Research Quarterly 46 (2):339-54.

Spaeth, Harold J., and Jeffrey A. Segal. 1999. Majority Rule or Minority Will: Adherence to Precedent on the U.S. Supreme Court. Cambridge: Cambridge University Press.

Stigler, George J. 1971. The Theory of Economic Regulation. Bell Joumal of Economics and Management Science 2 (1):3-21.

Stone, Christopher D. 1975. Where the Law Ends: The Social Control of Corporate Behavior. New York: Harper \& Row.

Sturm, Susan. 2001. Second Generation Employment Discrimination: A Structural Approach. Columbia Law Review 101 (3):458-568.

Sunstein, Cass R., David Schkade, and Lisa Michelle Ellman. 2004. Ideological Voting on Federal Courts of Appeals: A Preliminary Investigation. Virginia Law Review 90:301-54.

Sunstein, Cass R., David Schkade, Lisa M. Ellman, and Andres Sawicki. 2006. Are Judges Political?: An Empirical Analysis of the Federal Judiciary. Washington, DC: Brookings Institution Press.

Sutton, John R., and Frank Dobbin. 1996. The Two Faces of Governance: Responses to Legal Uncertainty in U.S. Firms, 1955 to 1985. American Sociological Review 61 (5):794-811.

Sutton, John R., Frank Dobbin, John W. Meyer, and W. Richard Scott. 1994. The Legalization of the Workplace. American Joumal of Sociology 99 (4):944-71.

Thornburg, Elizabeth G. 1999. Giving the "Haves" a Little More: Considering the 1998 Discovery Proposals. Southem Methodist University Law Review 52:229-65.

Wahlbeck, Paul J., James F. Spriggs, and Forrest Maltzman. 1998. Marshalling the Court: Bargaining and Accommodation on the United States Supreme Court. American Joumal of Political Science 42 (1):294-315.

Wald, Patricia M. 1998. Summary Judgment at Sixty. Texas Law Review 76:1897-1945.

Weick, Karl E. 1976. Educational Organizations as Loosely Coupled Systems. Administrative Science Quarterly 21 (1):1-19.

Wistrich, Andrew J., Chris Guthrie, and Jeffrey J. Rachlinski. 2005. Can Judges Ignore Inadmissible Information? The Difficulty of Deliberately Disregarding. University of Pennsylvania Law Review 153 (4):1251-1345.

Yoon, Albert. 2003. Love's Labor's Lost? Judicial Tenure Among Federal Court Judges: 19452000. California Law Review 91 (4):1029-60.

\section{CASES CITED}

Anderson v. Liberty Lobby, 477 U.S. 242 (1986).

Burlington Indus., Inc. v. Ellerth, 524 U.S. 742, 764-65 (1998).

Faragher v. City of Boca Raton, 524 U.S. 775, 778, 807-08 (1998).

Furnco Constr.Co. v. Waters, 438 U.S. 567, 577 (1978).

Grubb थ. W. A. Foote Mem'l Hosp., Inc. 74dl F.2d 1486 (6th Cir. 1984). 
Lacy v. Ameritech, 142 F.3d 440 (7th Cir. 1988).

Leopold v. Baccarat, 82 Fair Empl. Prac. Cas (BNA) 105, 2000 WL 174923 (S.D.N.Y. 2000), aff d 239 F.3d 243 (2d Cir. 2001).

McDowell v. Mississippi Power $\mathcal{E}$ Light, 641 F. Supp. 424 (S. D. Miss. 1986).

Meritor Sav. Bank v. Vinson, 477 U.S. 57 (1986).

Reeves v. Sanderson Plumbing Prods., Inc., 530 U.S. 133 (2000).

Schartz v. Unified Sch. Dist. No. 512, 953 F. Supp. 1208 (D. Kan. 1997).

\section{STATUTES CITED}

The Age Discrimination Act of 1967, 29 USCA $\S 621$ et seq. (Pub. L. 90-202) (ADEA) as amended.

The Americans with Disabilities Act of 1990, 42 USCA $\S 12101$ et seq. (Pub. L. 101-336) (ADA) as amended.

The Civil Rights Act of 1866, 42 USCA $\S 1981$ (14 Stat. 27-30) as amended.

The Civil Rights Act of 1871, 42 USCA $\S 1983$ (17 Stat. 13).

The Equal Pay Act of 1963, 29 USCA $\S 621$ (d) et seq. (Pub. L. 88-38) (EPA) as amended.

The Family and Medical Leave Act of 1993, 29 USCA $\$ 2601$ (Pub. L. 103-3) (FMLA).

The Rehabilitation Act of 1973, 29 USCA $\S 791$ et seq. (Pub. L. 93-112) (Rehab. Act), as amended.

Title VII of the Civil Rights Act of 1964, 42 USCA $\S \S 2000$ e et seq. (Pub. L. 88-352) (Title VII), as amended.

\section{APPENDIX 1: ROBUSTNESS CHECKS}

Our results are robust to various model specifications. Table A1 presents the results from four robustness checks, along with the coefficients from Model 4 for comparison. First, we explore an alternate definition of judicial deference. For the analyses discussed in the main text, we coded deference as occurring when judges (1) did not consider adequacy at all, (2) paid lip service to adequacy, or (3) concluded that a structure was inadequate but explicitly stated that inadequacy does not matter. We defined lip service as occurring when an opinion stated that a structure was adequate but also included facts that made it self-evident that the structure was inadequate. We only coded lip service in very extreme examples and in cases in which two coders agreed that lip service had occurred. However, since the lip service category is more subjective than the other two forms of deference, we reran all analyses with lip service excluded from the definition of deference. Model Al uses a recoded deference variable that includes only structures in which judges did not consider adequacy or explicitly stated that inadequacy did not matter. The deference coefficients are almost identical to those in Model 4. One difference is that the interaction effect between deference and judicial conservatism is now only significant at the $p<.1$ level $(p=.051)$. Model A1 demonstrates that the lip service cases are not driving the deference results reported in the main text.

Second, an alternate explanation for our findings could be that certain judges are more likely to defer to structures and that those same judges are predisposed to favor employers. The fact that we coded multiple opinions from some judges allows us to explore this possibility empirically. Our sample includes multiple opinions from 198 


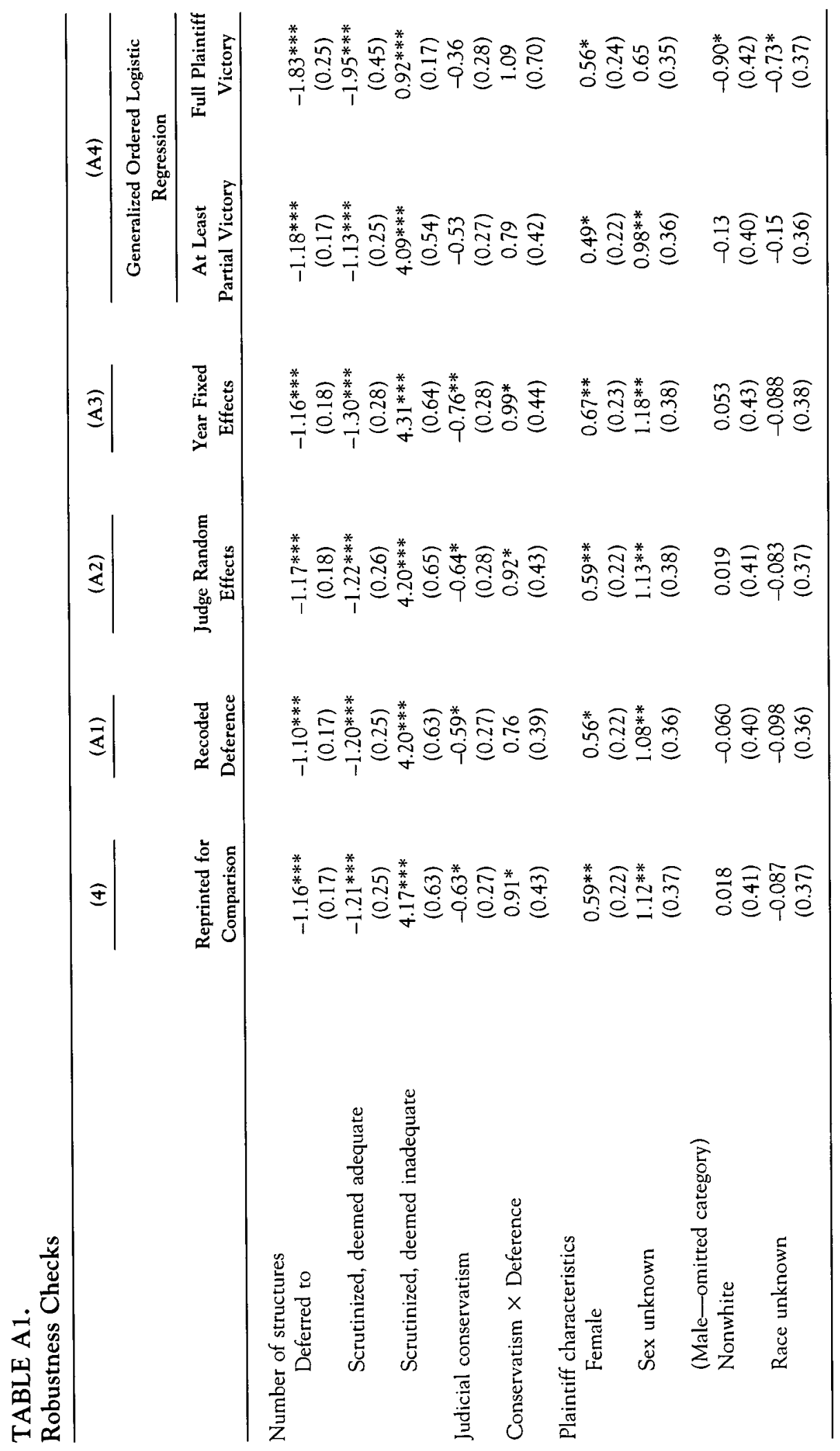




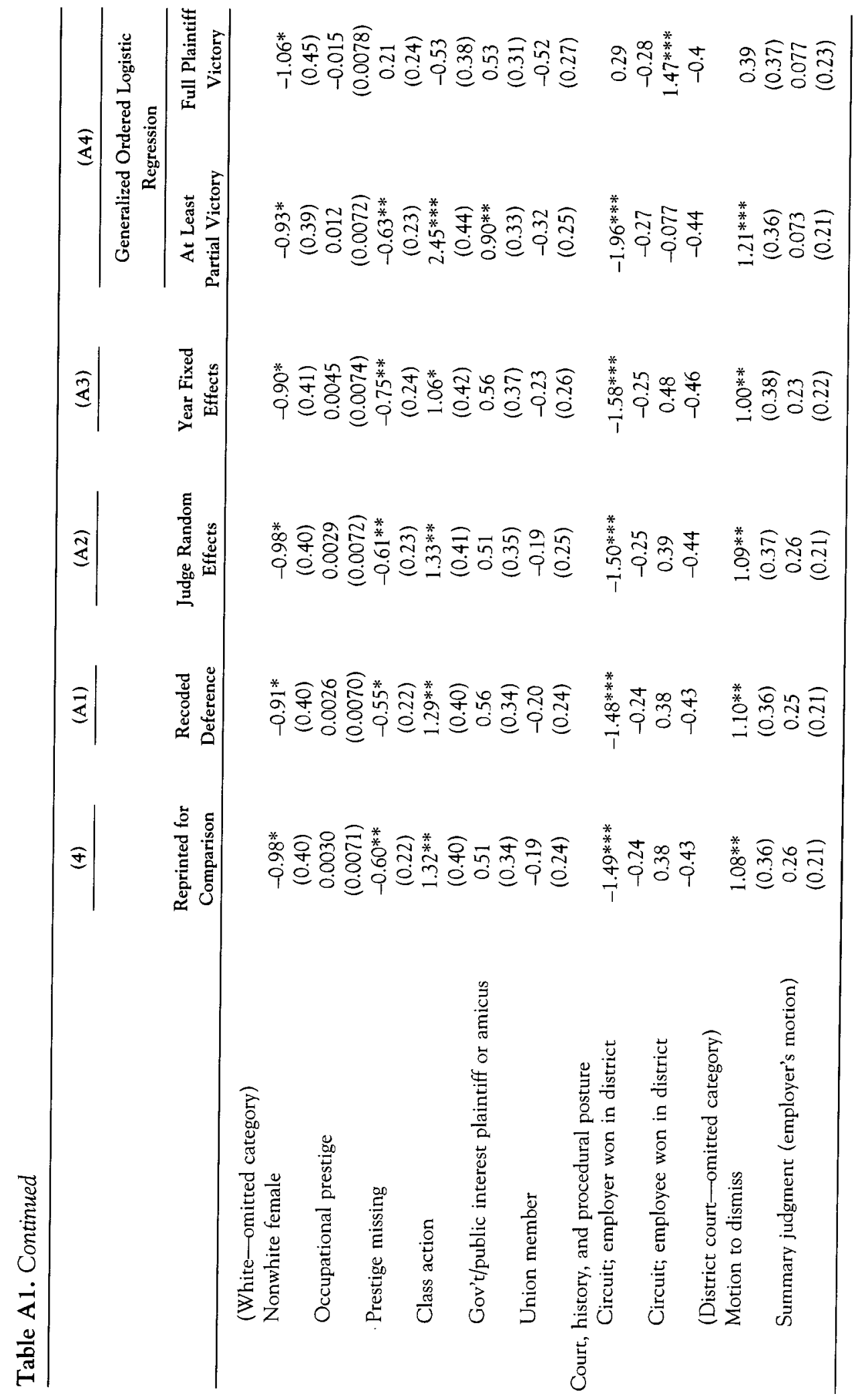


876 LAW \& SOCIAL INQUIRY

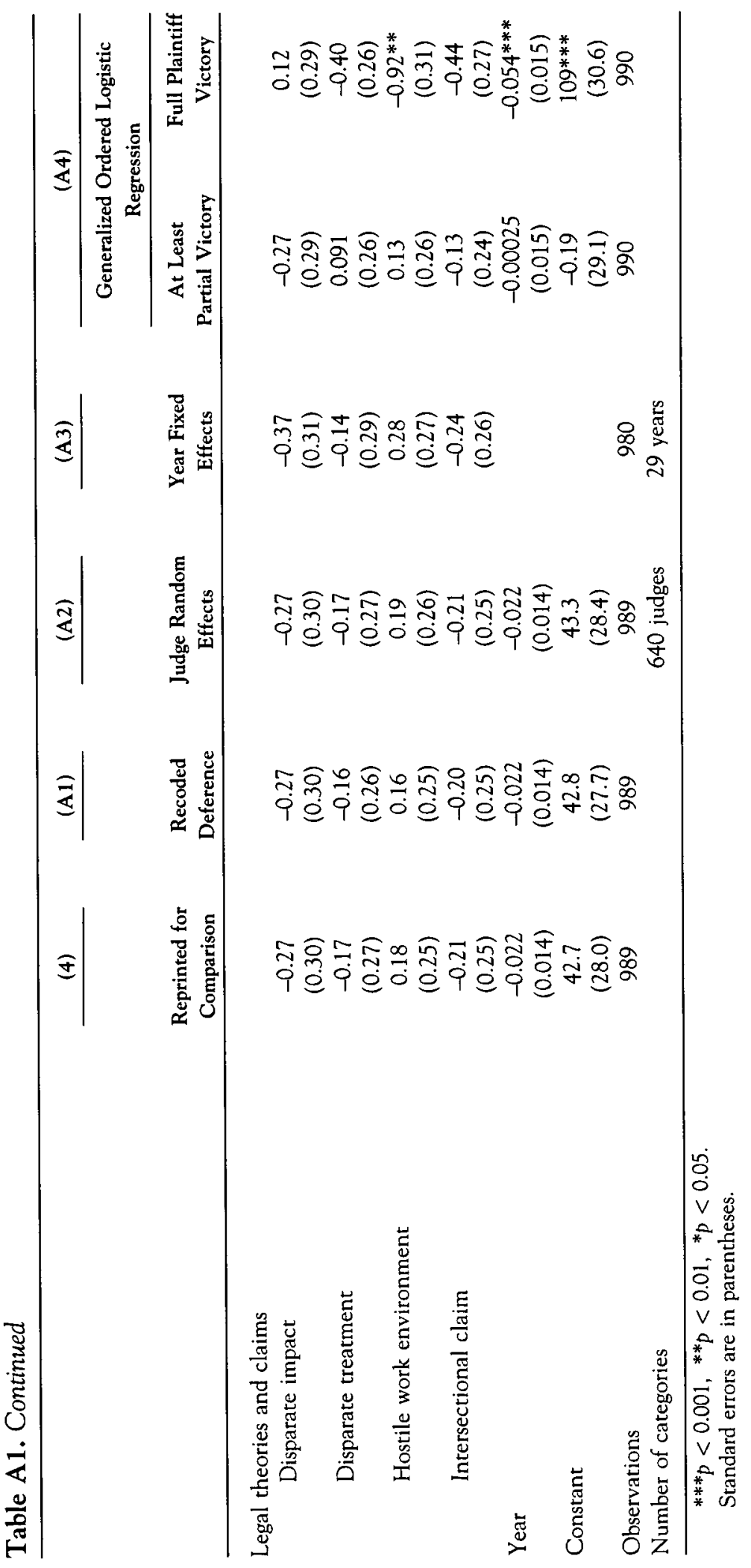


judges (out of a total of 670 judges). (In the circuit court, we classify opinions as by the same judge when that judge wrote the majority opinion, even though other judges served on the panel.) We began by adding judge fixed effects to Model 2. (We did not add them to Model 4 because in the district court, our measure of judicial conservatism only varies between judges.) With the judge fixed effects in the model, the deference effect becomes slightly larger, moving from -1.10 to -1.17 . (Full results from the fixed effects model are not presented in Table A1, which compares alternate specifications of Model 4, but are available from the authors upon request.) Thus, even when comparing opinions written by the same judge, employers are more likely to prevail when the judge defers to more structures.

Random effects allow us to account for unmeasured characteristics of judges in models that include measures of judicial conservatism. Model A2 adds judge random effects to Model 4 with virtually no change in the coefficients. Since the intraclass correlation is not significantly different from zero, we do not include random effects in the models presented in the main text. The fact that the inclusion of judge fixed or random effects does not diminish the deference coefficients indicates that unmeasured characteristics of judges cannot account for the relationship between deference and case outcome.

Third, since both deference and employer victory rates have increased over the years, it is especially important to control adequately for changes over time. The models discussed in the main text include a linear year variable. Model A3 replaces this variable with year fixed effects to account for any nonlinear time trends. In Model A3, the coefficients for structure types and judicial politics actually increase slightly as compared to Model 4. Thus, changes over time cannot explain away the deference effect; even within years, deference and case outcome are significantly related to one another.

Fourth, we chose to simplify the results presented in the main text by collapsing our dependent variable to two categories. However, our coding scheme included a more sensitive measure of case outcome. Model A4 presents results from generalized ordered logistic regressions of a three-category dependent variable (employer victory, mixed outcome, and plaintiff victory). The results from this model are presented in two columns, predicting first the odds of at least a partial plaintiff victory (as opposed to a complete defendant victory) and, second, the odds of a complete plaintiff victory (as opposed to an at least partial defendant victory). Our key results are similar, with one exception: the effects of judicial conservatism, and its interaction with deference, are now only significant at the $p<.1$ level. However, they remain similar in magnitude.

\section{APPENDIX 2: ORGANIZATIONAL STRUCTURES}

TABLE A2.

\section{Organizational Structures and Their Frequencies}

Compliance Structures: Ways to complain and explicit efforts at preventing discrimination 
Simple policy prohibiting illegal activity

HR office with explicit EEO function

Informal open-door policy (not written but exists in practice)

Employer's offer of accommodations

Employer's willingness to discuss accommodations

Formal open door policy (written statement that boss's door always open)

No written policy but court says employer generally follows a process that indicates fairness

Diversity office or officer

Legally required poster

Other explicit efforts at preventing discrimination (e.g., AAP)

Other ways to complain

Standardized Personnel Practices/Policies

Evaluation procedure (including rebuttal and complaints;

including quantitative rating systems)

Other standardized personnel practices/policies (must be ongoing/non-ad-hoc practice)

HR office with $\mathrm{NO}$ explicit EEO function

Multiperson decision-making process, formal

Progressive discipline policy (verbal warning, written

warning, fired)

Seniority/tenure policy

Training program (may be external to organization)

Job posting/notice of interest in new job

Written job description

Employee handbook

Multiperson decision-making process, informal

Record-keeping procedure

Leave policy (including rules for giving notice) 5

Attendance policy

Recruitment program

Policy regarding notice time for leave

Generalized Employer Prerogatives

Define job and allocate tasks (including restructuring)

Restructuring (reduction in force, downsizing involving job loss)

Subjective evaluation criteria (e.g., leadership skills), use of

Other employer prerogatives (must be ongoing/not adhoc practice; includes objective, ongoing performance standards [e.g., quota])

Tests, use of

Workplace behavioral rules 
Table A2. Continued

\begin{tabular}{lc}
\hline Structure & $\begin{array}{c}\text { Percent of Opinions } \\
\text { Referencing Structure }\end{array}$ \\
\hline Set time, place, and attendance (including restructuring) & 2 \\
Inside candidates, preference for & 2 \\
Word-of-mouth recruitment, use of & 2 \\
Physical requirements (age, weight, height) & 2 \\
Appearance requirements & 2 \\
Set pay based on competition, availability, labor market & 1 \\
Language skills, including good English or no accent, & 1 \\
preference for & 1 \\
Set pay based on employer's special needs & 1 \\
Recent education, preference for & \\
\hline
\end{tabular}

